\title{
Fractured communities: Natural gas, resource control, and social response in Bradford County, PA
}

Chad F. Spade

West Virginia University

Follow this and additional works at: https://researchrepository.wvu.edu/etd

\section{Recommended Citation}

Spade, Chad F., "Fractured communities: Natural gas, resource control, and social response in Bradford County, PA" (2013). Graduate Theses, Dissertations, and Problem Reports. 144.

https://researchrepository.wvu.edu/etd/144

This Thesis is protected by copyright and/or related rights. It has been brought to you by the The Research Repository @ WVU with permission from the rights-holder(s). You are free to use this Thesis in any way that is permitted by the copyright and related rights legislation that applies to your use. For other uses you must obtain permission from the rights-holder(s) directly, unless additional rights are indicated by a Creative Commons license in the record and/ or on the work itself. This Thesis has been accepted for inclusion in WVU Graduate Theses, Dissertations, and Problem Reports collection by an authorized administrator of The Research Repository @ WVU. For more information, please contact researchrepository@mail.wvu.edu. 


\title{
FRACTURED COMMUNITIES: NATURAL GAS, RESOURCE CONTROL, AND SOCIAL RESPONSE IN BRADFORD COUNTY, PA
}

\author{
Chad F. Spade
}
Thesis Submitted to the College of Arts and Science at West Virginia University
in partial fulfillment of the requirements
for the degree of

\author{
Master of Arts \\ In \\ Geography \\ Dr. Bradley Wilson- Chair \\ Dr. Ann Oberhauser \\ Dr. Jeremia Njeru \\ Department of Geology and Geogrpahy
}

Morgantown, West Virginia

2013

Keywords: Natural Gas; Marcellus Shale; Social Fracturing; Environmental Justice; Accumulation by Dispossession; Bradford County

Copyright 2013 Chad F. Spade 


\section{Abstract \\ FRACTURED COMMUNITIES: NATURAL GAS, RESOURCE CONTROL, AND SOCIAL RESPONSE IN BRADFORD COUNTY, PA}

Chad F. Spade

This thesis examines natural gas drilling in the Marcellus Shale formation through a case study and research conducted in Bradford County, Pennsylvania. Drawing upon the literatures of environmental justice and accumulation by dispossession, this thesis examines the impacts natural gas drilling has on the local community. Themes of economic benefits, leasing procedures, environmental concerns, social fracturing and political power are explored as they relate to the natural gas industry's impact on the local community. Viewed through the theories of accumulation by dispossession and environmental justice, this thesis examines the role resource control plays in the development and exploitation of natural gas. 
$\begin{array}{ll}\text { I. Introduction } & 1\end{array}$

II. Literature Review- Geographies of Justice 5

a. Accumulation by Dispossession 5

b. Environmental Justice 13

i. Distributive 14

$\begin{array}{ll}\text { ii. Procedural } & 17\end{array}$

$\begin{array}{lr}\text { III. Methods } & 19\end{array}$

$\begin{array}{ll}\text { a. Archival Research } & \mathbf{2 0}\end{array}$

b. Key Informant Interviews $\quad 24$

$\begin{array}{lr}\text { IV. The Natural Gas Grab } & \mathbf{2 8}\end{array}$

V. Community Response 33

a. Speculative Economics $\quad 34$

b. Leasing Labyrinths and Unjust Distribution of Benefits 39

c. Ambivalent Environmentalism 43

$\begin{array}{ll}\text { d. Social Fracturing } & 47\end{array}$

e. Power (in the) Play $\quad 54$

VI. Discussion: Losing Control $\quad 58$

VII. Conclusion $\quad 66$

$\begin{array}{lr}\text { VIII. Works Cited } & \mathbf{7 0}\end{array}$

$\begin{array}{lr}\text { IX. Appendix } & 75\end{array}$ 
a. Figures

b. Tables

c. Figures

d. Appendix A

83 


\section{Introduction}

Throughout Bradford County, Pennsylvania, large drilling platforms slowly chew into the earth, reaching back in time though geologic history to find rich deposits of natural gas created millions of years ago in the Marcellus Shale formation. Day in and day out, these drilling platforms slowly plod their way deeper and deeper, searching for energy reserves to power our modern world. Aside from their large towers jutting out of mountain forests and green pastures, the work of these mighty industrial assemblages below the subsurface goes unnoticed, often hidden from view on private lands, forests, and farms. Bradford County sits atop one of the most productive areas of the Marcellus shale formation, with a shale thickness of between 100 to 250 feet and at a much shallower depth of between 4000 and 7000 feet beneath the surface (MCOR, 2010). In the context of Marcellus Shale drilling, Bradford County has received more attention than any other county in the state and in the larger Marcellus shale region. As of January 2012 there were 2,105 active or permitted gas wells in the county (See Figure 1) (PA DEP, 2012). There is so much drilling activity occurring in the county that it has been termed as a hot spot for natural gas activity and many people see Bradford County as the model for drilling across the region (Detrow, 2011).

However, in April 201, the blowout of a well owned and operated by Chesapeake Energy ${ }^{1}$ thrust Bradford County gas drilling activities into the center of a national debate about Marcellus Shale development and the use of hydraulic fracturing. The blowout which lasted 12 hours, spilled out tens of thousands of gallons of toxic fluid. Catchment ponds designed to retain excess fluid around the gas well were already near capacity from a large rainstorm that had

\footnotetext{
${ }^{1}$ In fiscal year 2011, Chesapeake Energy reported yearly revenue of $\$ 11.635$ billion (Chesapeake Energy Corporation, 2012).
} 
passed through the area just days before. The ponds failed and the fluid rushed into nearby pastures, eventually finding their way to a local stream. The blowout forced the evacuation of seven homes and contamination of local water sources used to graze livestock (Hrin, 2011). While no injuries were reported as a result of the blowout, the evacuated families were concerned about potential consequences of the contamination caused to their land/property. Nevertheless, the Pennsylvania Department of Environmental Protection fined Chesapeake $\$ 250,000$ for the contamination, the highest fine possible under current state law (Philips, 2012). Beyond the local environmental consequences of the blowout, media coverage of the event fueled an already raging national debate surrounding hydraulic fracturing. This debate is dominated by two opposing groups: environmental activists and energy companies.

Environmental activists are concerned about the contamination of land and water while energy companies tout the contribution to local job creation and revenues to landowners from royalties. Often absent from this debate however are the antecedents to the natural gas boom, the voices of local residents affected by natural gas drilling. In this thesis I argue we must drill down below these surface debates into the social and contemporary history that put natural gas on the map in Bradford County. What are the recent conditions that allowed for drilling to occur? What are the current benefits or consequences of natural gas drilling in the region? How do local residents respond to the changing social landscape of their region in terms of resource control?

Today Bradford County boasts more wells drilled into the Marcellus Shale formation than any other county in the state of Pennsylvania (See Figure 3). Hotels and businesses bustle with activity, not from tourists coming to enjoy the region's beauty but throngs of men who've come to drill for the nation's fuel of tomorrow-natural gas. In the last five years Bradford 
County has moved from a sleepy rural community into an epicenter of the Marcellus Shale boom. Economic and environmental concerns dominate the debate of the natural gas industry, grabbing headlines weekly in the local media.

However, missing in the debate is how the gas boom has trigged a massive resource grab for gas rights by private firms throughout the Marcellus Shale region. In this thesis, I argue that current injustices are a direct result of the massive resource grab that has taken place in the county and has dispossessed local residents of their control over the resource and is an issue of socio-environmental injustice. I argue that resource control must be the starting point from which to understand the current debates and community responses.

A long history of dispossession, resource control and exploitation exists throughout the Appalachian region. This has occurred through waves of capital investment and flight from the region and boom and bust cycles of resource extraction. Natural gas represents the new face of resource extraction and exploitation in Appalachia as capital investment seeks new profits from a traditionally exploited region of the country. In addition to its long history of exploitation, Appalachia also has a long history of resistance and dissent, with many social movements growing out of the conflict between unjust benefits and burdens. This regional history is an important informer to the story that has begun to play out. My study therefore analyzes the histories and community perspectives on this resource grab and its effects through its epicenter, in Bradford County, PA.

This first section of the thesis discusses the theories of accumulation by dispossession and environmental justice, specifically procedural and distributive justices which frame this research. Second, I describe the methods used to conduct my research. Specifically, I discuss 
the archival data used, including local, regional, and national newspapers, and semi-structured interviews conducted with key informants in the town of Towanda. The methods section also describes the process used in developing a coding structure and the textual analysis that was conducted on both the newspaper articles and the interview transcripts. Third, I introduce the case study of resource grabbing in Bradford County, examining the significance of the Marcellus Shale formation as well as exploring the ways in which the resource acquisition played out in the county. Using secondary data collected from newspapers, I illustrate the coherence of using the theory of accumulation by dispossession in explaining the corporate resource grab for natural gas in Bradford County. Fourth, after my literature review, methods and case description, I examine the ways that the local community has responded to the gas boom. Drawing primarily from key informant interviews and local newspaper articles, this section examines the ways in which communities in Bradford County make sense of the economic, environmental, social and political dynamics of gas drilling in the county. The speculative nature of the economic and environmental discourse looks at the way in which economic benefits and environmental negatives are perceived by local residents. These speculative discourses stand in direct contrast to the reality of the social discourse that is taking place in the county, in terms of new social problems facing the community. These new conflicts and impacts represent a major social fracturing of everyday life in the region. Fifth, I examine the emerging political discourse that is seeing power being stripped away from local communities and property owners and being centralized into the hands of the state as a means to facilitate continued expansion of the gas industry. I conclude with a discussion of losing control over wider aspects of community life and local decision-making processes caused by the resource grab. 


\section{Geographies of Justice: Accumulation by Dispossession and Resource Control}

This research builds on an emerging literature in geography that explores the processes of dispossession at the root of contemporary capitalist development. Moreover, I explore community responses to the direct and indirect effects of dispossession on economic, environmental, social and political life in Bradford County. This literature review examines the theory of accumulation by dispossession (Harvey, 2003) with the theory of environmental justice. It is my goal to develop a conceptual framework for analyzing resource acquisition and community responses from these literatures as a way to create a more complete picture of resource extraction activities and their impacts upon local communities. By utilizing this approach I hone in on a "loss of resource control" in Bradford County that has subsequent negative economic, environmental, social and political effects for county residents. To proceed, I begin by explaining the concept of accumulation by dispossession (Harvey, 2003), then turn to concepts within environmental justice (distributive and procedural equity).

\section{$\underline{\text { a. Accumulation by Dispossession }}$}

"The creation of new spaces of accumulation is not an innocuous process; it inevitably involves the forceful and violent reorganization of peoples' lives as they are subordinated to the whims of capital" (Gordon and Webber, 2008).

In his book The New Imperialism, David Harvey develops the concept of accumulation by dispossession to explain the strategic response by capital investors to maintain growth during financial crisis. The theory of accumulation by dispossession returns to central debates within Marxian economics about how capital resolves crises of overaccumulation. Harvey, drawing 
from Rosa Luxemborg, argues that amidst a period of crisis, capital will seek new investment opportunities to maintain growth and stability. To avoid the devaluation of capital surplus, new investments or projects are created to "mop up" excessive capital and thus return the system to stability. As Luxemburg $(1951,84$ ) points out, "the crisis tendencies of capitalism identified by Marx made the constant conquest of non-capitalist territories for the expropriation of raw materials and the reinvestment of surplus a requirement for capitalist stability." Harvey (2003) identifies three ways in which capital will attempt to secure continued growth during a period of overaccumalation crisis: 1) by the opening up of new markets, 2) by obtaining cheaper inputs such as labor or resources, or 3) by gaining legal control over new assets.

Harvey argues that overaccumulation in the 1970s triggered the need for a new strong legal framework that could facilitate the flow of capital. Neoliberalism and specifically the efforts to deregulate and reduce trade barriers provided the needed regulatory framework for capital accumulation and privatization created new assets for profit and growth. To avoid devaluation, capital must continue to find profitable opportunities to absorb surplus (Harvey, 2003). Privatization is the critical element within this capitalist strategy to resolve overaccumulation. Harvey refers to privatization as the "cutting edge of accumulation by dispossession" (Harvey, 2003: 96). As Glassman argues "privatization in myriad forms, is one of the crucial ways in which capitalists have been able to 'actively manufacture' new realms for proletarianization and private appropriation of public property, even within the global core" (Glassman, 2006: 620). Furthermore, according to Harvey (2003: 88), "the production and reconfiguration of space relations provides one potent way to stave off, if not resolve, the tendency towards crisis formation under capitalism." The relationship of space and capital has 
become extremely important in understanding the ways in which capital seeks out previously undeveloped regions to absorb surplus and avoid devaluation. Harvey terms this as "spatiotemporal fixes to the capital surplus problem" (2003:89). Capital overaccumulation, therefore, is an important driver of territorial expansion and development as a means to absorb capital over time:

"The production of space, the organization of wholly new territorial divisions of labour, the opening up of new and cheaper resource complexes, of new regions as dynamic spaces of capital accumulation and penetration of preexisting social formations by capitalist social relations and institution arrangements (such as rules of contract and private property arrangements) provide important ways to absorb capital and labour surpluses" (Harvey, 2003: 116).

The power of the state plays a crucial role in providing the mechanism for the accumulation. It is in the capitalist state's interest to maintain legitimacy and avoid devaluations of over-accumulated capital. As Arendt $(1964,28)$ suggests, "the original sin of simple robbery which made possible the original accumulation of capital had eventually to be repeated lest the motor of accumulation suddenly die down." Dispossession of land or resources has become an essential means of capital reproduction. To this end, the state is able to use its extra-economic and coercive power to open new markets and territories for the expansion of capital or to obtain cheaper raw materials. Related to this, Harvey (2003) argues that the invasion of Iraq was a way to open new territory to capital exploitation and at the same time increase profits by obtaining cheaper raw materials, in this case, oil to fuel global markets and maintain American economic dominance. The opening of state owned oil fields in Iraq through 
war, to global capital represents the power the state may employ to secure the needs of continued capital growth (Harvey, 2003). When powerful states do not act unilaterally, they can operate indirectly through organizations such as the World Bank or IMF, through structural adjustment programs that require economies to privatize their assets and open their doors to surplus capital or through development projects that absorb large amounts of global capital for the building of dams or other structural projects that do little to benefit local populations but instead return profits to wealthy investors.

We can also see the effects of accumulation by dispossession in Latin America, Asia and Africa. In Africa, a modern day resource grab for petroleum reserves is well underway, with players such as Exxon, Chevron, Shell and BP, and a farm land grab is converting domestic food production into agro-food production for multinationals and countries such as China, South Korea and Saudi Arabia (Fairhead, Leach and Scoones, 2012). Similarly in Latin America and Africa we are witnessing the appropriation and leasing of large amounts of farm land, the acquisition of mining rights, and forest rights to multinational firms (Spronk and Webber, 2007, Schroder, 2010, Watts, 2008, Kaup 2010). Both domestically and internationally, states enable the formation of new markets and protect resource rights to facilitate the flow of excess capital and thus generate stability and profit (Gordon and Webber, 2008). In Peru the surge in the acquisition of gold mining rights by Toronto based mining company Barrick Gold Corporation has led to conflicts between the company and rural communities that see little to no benefits from the expropriation of their lands (Himley, 2013). In Tanzania, local people have been excluded from the mining of Tanzanite as large international mining corporations have acquired the mining rights from the government and sealed off the area from local miners as a way to 
secure the commodity chain (Schroeder, 2010). Beyond the sphere of mining a new crisis or speculation has emerged and fueled a rush to control land in the Global South for the production of food and energy. The need for continued capital accumulation is driving the expropriation of land from local people to multi-national corporations for the development of industrial production. This includes the conversion of land from subsistence agriculture into profit driven export of food and biofuels (Borras and Franco, 2012). All of these projects are accomplished through dispossessing local peoples control over their resource (land, gold, oil, tanzanite, etc.) and opening the resource to global markets and capital.

Accumulation by dispossession is also evident in the green revolution's attempt to modernize agriculture, as corporations created new markets and raw materials for exploitation. Using new technologies firms created high yielding new crop varieties which in turn required large capital inputs to maintain and seeds to be bought each year. This in essence was a privatization of food production as corporations used the legal framework to patent and gain control over seed varieties, effectively severing the individual from the process and control over their crops (Fitting, 2011). The development of new laws protecting intellectual property gave protection to corporations in developing and exploiting these new innovations. The power of the state was employed through legal means to protect the interest of capital and create new markets. Similar to the way in which state power was used to open up new markets in foreign countries, the power of the state could be employed to create new markets through a legal means.

More recently a new speculative land grab has begun in which the commodification of nature has become a new outlet to soak up excess capital. As Fairhead et al, (2012) point out, this 'Green Grabbing' represents a new market for capital exploitation created through a new valuation of ecological systems. Breaking down ecological systems based upon value and then 
privatizing the environment as a means of preservation, nature has now been drawn into financialized markets. While in practice this concept of Green Grabbing appears to leverage capital for conservation, it also opens environmental systems up to exploitation in times of capital crisis. As capitalism needs to maintain profitability, these environmental systems will become increasingly exploited.

Accumulation by dispossession inherently results in social struggles or conflicts which take many forms including, protests, legal suits, sit ins, road blockades, occupations and other forms of social disobedience. Many of the ways in which people protests and express their dissatisfaction with issues of accumulation by dispossession mirror the ways in which the environmental justice movement mobilizes people to resist environmental degradation. It is therefore, important to note that in many ways, the environmental justice movement arose from precisely the kinds of economic, environmental, social and political effects caused when people were dispossessed from their land, communities, and overall wellbeing. For example, environmental justice movements have developed in Bolivia to challenge the privatization of the country's natural gas and petroleum resources. Large social uprisings and demonstrations were used by the local population to protest against the foreign investment projects that were seen as taking the wealth of the resource from the local economy and transferring it instead to the transnational corporations.

The privatization of natural gas and oil resources in Bolivia clearly demonstrates Harvey's idea of accumulation by dispossession. Expanding on Harvey's idea, Spronk and Webber (2007: 34) explain that, "[a]ccumulation by dispossession is not merely privatization of formerly state or public resources, but their acquisition by transnational capital in the U.S. and other core economies." As such, the privatization of the natural gas and oil resources in Bolivia 
has opened the country up to more foreign investment and capital, allowing for greater exploitation of its resources and removal of millions of dollars from the Bolivian economy. Accordingly, local communities have mobilized and organized, including the mobilization of indigenous and impoverished members of society, to resist the exploitation of their resources, forcing the nationalization of the gas industry. Yet the reversals of neoliberal policies are extremely challenging and not easily accomplished. Even while a country may want to exit the arrangements, powerful barriers exist, effectively locking the country into the neoliberal policies and arrangements that have been created (Kaupp, 2010). This raises critical questions about the efficacy of social movements challenging accumulation by dispossession when states choose to protect capital over the interests over their own citizens. But these are not just third world problems.

As several scholars note, the processes of accumulation by dispossession are taking place in the first world as well (Wolford 2012, Watts 2006, Malin, Himley, 2013, Strauss, 2010). Many stories of dispossession can also be gleaned from the Appalachian region that has seen entire mountains removed and communities displaced in the name of coal mining, jobs and progress (Fisher, 1993). The dispossession of land and a way of life generated social uprisings and disobedience throughout the region as communities protested their loss of land and livelihoods. Historically in the case of Appalachia, the interests of the subsurface rights owner normally supersede that of the surface owners' rights. Bingman describing strip mining in Kentucky notes that "the mineral owner's right to mine superseded the surface owner's right to clean water, sacred graves, or a front yard" (Bingman, 1993).

This is the case in Bradford County, where gas companies sign leases with private landowners and bring resources under their control. People who have leased their land or lost 
control of their mineral rights are still however severed from their control over that resource and dispossessed from utilizing or exploiting it, at least for as long as the lease is maintained and enforced. The rule of law in enforcing these leases is guaranteed by the state and thus the state becomes the facilitator for the dispossession and the reproduction of capital in the natural gas industry in Bradford County.

The state of Pennsylvania has introduced legislation to override local regulation over the resource and effectively make it easier for the investment and exploitation of the resource by the gas industry. The legislation is known as House Bill 1950, and strips away the authority of local municipalities to zone against activity related to the gas industry. Through this law, the state effectively enables the opening up of more land and resources for investment and development. Often these policies are shrouded in the language of promoting a greener economy. Natural gas is being championed as a cleaner burning alternative fuel to petroleum. Natural gas has in fact been billed as a bridge fuel, to help make the transition from oil to cleaner energy in the state (Plumer, 2013). The claim of natural gas as being an environmentally friendly alternative to the countries energy needs has engendered considerable speculative investment and created a frenzy for the acquisition and exploitation of this resource.

Unlike in Bolivia, land in Bradford County where gas drilling is taking place has for the most part remained private, although the county has also leased some public land. Yet, the concept of accumulation by dispossession is applicable to the scenario in Bradford County. The largest lease holder in the county, Chesapeake Energy, relies on global capital to finance their leasing and drilling activity, being a publicly traded company allows them access to global financial capital, along with brokering deals with multi-national banking firms (Goodell, 2012 ). Therefore, Bradford County has become a destination for the offloading of global capital surplus; 
much like Bolivia had been a few decades earlier. There are also similarities between the social resistances that took place in the two regions. While the protests and social discourse in the county are not as militant as the ones in Bolivia, there is still a social backlash occurring in the region over social problems arising as a result of resource exploitation. A backlash rooted in feelings of what I call a "loss of control" which is just beginning to materialize into collective response.

\section{$\underline{\text { b. Environmental Justice }}$}

While accumulation by dispossession is based on the examination of capital flows and the way in which capital operates, environmental justice examines the effects and consequences of these capital flows and the ways that communities respond.

Environmental justice refers to those cultural norms and values, rules, regulations, behaviors, policies and decisions to support sustainable communities where people can interact with confidence that the environment is safe, nurturing and productive. Environmental Justice is served when people can realize their highest potential....Environmental justice is supported by decent paying safe jobs, quality schools and recreation; decent housing and adequate health care; democratic decision making and personal empowerment; and communities free of violence, drugs and poverty. These are communities where both cultural and biological diversity are respected and highly revered and where distributed justice prevails. (Mutz, 2002: 17-18).

By examining the environmental justice literature within the context of a dispossession of mineral rights, I argue that we can gain a different perspective on how to address resource injustices. Research on environmental justice opens up possibilities to thinking through community responses to the distribution of environmental burdens and benefits as well as decision-making about the distribution of environmental goods and bads. By considering the effects of accumulation by dispossession and community responses to it through the analysis of the natural gas industry - I can also explain the temporal dimension of the changing social landscape as new issues arise and perceptions change over time. Through my analysis of 
community responses to the natural gas industry I hope to provide a critical framework in which social injustices can be studied and further understood not only in the context of their environmental negatives but within the context of resource control in Bradford County, Pennsylvania.

\section{i. Distributive Justice}

Environmental justice tends to be understood through two notions of justice - distributive and procedural. Distributive justice examines how benefits and burdens are distributed throughout society and the marginalization that occurs as a result (Mutz, Bryner, Kenney, 2002). The idea of distributive justice has roots in the theory of utilitarianism. According to this theory, distributive justice involves "a distribution of benefits, opportunities and burdens that generates the greatest welfare for the greatest number" (Bryner, 2002: 40). Within the environmental justice movement distributive injustice refers to the unequal distribution of environmental goods (like parks) and bads (like toxins). This idea of distributive justice emerged from the civil rights movement in requiring all federal programs be nondiscriminatory. Yet in his book Dumping in Dixie, Bullard (2000) examines how race was the major factor in the siting of hazardous waste sites and that minority groups were more prone to exposure of environmental bads.

This distributive injustice unfairly burdened a minority group through the siting of hazardous waste sites, while the majority group benefitted from no contamination of their environment (Bullard, 2000). The study also examined the power dynamics that exist in relation to environmental decision making. More recently concerns of environmental racism have grown to include the idea of white privilege in terms of the distribution of environmental burdens and benefits. In the case of Los Angeles, Pulido (2000) explores how the historical privilege granted 
to whites has allowed whites to distance themselves from environmental negatives, while nonwhites are forced to suffer the environmental burdens. These studies of environmental racism have played a key role in examining the power relations based upon race and class that exist in distributional injustices.

The major issue is assessing exactly what is fair and equal and how can resources be distributed and shared equally when in many cases a geographic component to this disparity exists. The creation of fair compensation so that all members of society can benefit from the environment, proves to be an extremely complex process of putting a monetary assessment on damage that has been done. When assessing distributional justice the case must be made that unfair practices are unevenly and unfairly burdening one segment of society over another. The nature of the capitalist system creates distributional injustice not only in the context of environmental burdens but also a distributional injustice to access to environmental resources.

There are two main ideologies to the concept of distributive justice. Utilitarianism shows up in environmental policy as a cost benefit analysis of risks vs. benefits. The problem with this concept lies within the decision of how to measure the costs and benefits. The concept that one community should be burdened with the waste of another merely to serve the greater good; is an unequal or unfair distribution of the environmental impacts associated with industrialized production (Bryner, 2000). It is in essence on one hand deciding which people should be burdened with the impacts of disease, health problems, loss of livelihood and destruction of their communities, so that on the other hand a larger group of people can benefit with consumer goods, pristine environments, clean air, and healthy communities. Appalachia with its relatively rural population has often been a victim of a utilitarian approach to the 
environment. The Appalachian region has been devastated by resource extraction, specifically coal that is used to provide cheap electricity for eastern cities. Environmental destruction is far removed from the minds and psyches of the population that is benefitting. Thus Appalachia is a prime region for exploitation, occurring in hills, valleys and towns that people rarely ever hear of (Bingman, 1993). The second opposing theory to utilitarianism is proposed by John Rawls. Rawls argues that "rights provide a framework that ensures individuals have the freedom to pursue their own vision of the good life as long as they respect the similar freedom of others." (Rawls, quoted in Bryner, 2002:43) Rawls presents the idea that an individual's rights cannot be sacrificed merely for the greater good. Rawls theory views society on the individualistic scale where each person's rights are equal to another person's and thus cannot be infringed upon.

In Bradford County, both of these concepts play out, there is both a collective burden being placed upon the community and also an individual burden being placed upon certain individual members of the community that are more negatively impacted. While crime, traffic, strains on social services, and loss of natural beauty affect the whole community, other problems such as well-contamination, increased rents and homelessness are mostly experienced at individual levels. In the context of utilitarianism a rural community is being burdened, so that other communities can benefit from cheap and clean burning natural gas, for instance east coast cities with a large population benefit, while a rather small rural population is burdened. Although resource extraction creates a collective burden upon the local population, the leasing structure is based upon individual property owners leasing their land. No framework exists for collective decision making on natural gas drilling. Beyond the burden shared by the community, certain individuals are more heavily burdened than others, specifically those individuals that are 
already in marginal socio-economic standing, (elderly, impoverished, renters, and minimum wage workers). As I discuss in detail below, evidence in Bradford County suggests that the gas industry has generated many problems which I argue constitute a distributive injustice. The theme of distributive injustice in the context of Bradford County will examine issues surrounding crime, increasing rent and traffic, homelessness, loss of scenic beauty, contamination, and degradation of social services. I also show how the current distributive injustice issues in the country are connected to the dispossession and loss of local control over mineral rights.

\section{ii. Procedural Justice}

The concept of procedural justice differs from distributive justice in that it examines the way in which people are able to respond to changes imposed upon them, either though legal, political or activist means. Procedural justice is a theory that attempts to look at the idea of fairness in the decision-making processes that helps to resolve disputes or allocate resources. Procedural justice is based on the idea that the public should play a direct role in the decision making process in regards to environmental policy, the siting of hazardous waste sites, and the extraction of environmental resources in their communities so that they can collectively divide benefits and burdens. It is based in the argument that people should have a right to influence decisions that may adversely impact their wellbeing, community or livelihoods. As Bryner (2001:45) points out, "justice may require the right to participate in a decision-making process, the right to have one's interests included in the analysis, or the right to be represented by others." Procedural justice thus concerns the potential outlets local residents can pursue to make their voices heard in negotiations with energy corporations and state and local regulatory agencies in regards to natural gas drilling activities. The procedural injustice being experienced today is a 
result of the loss of control over gas resources in the region, which has severely limited the role local residents play in decision making. Sheila Foster writes that "the emphasis on communitybased decision making in the environmental context is, to be sure, a clear paradigm shift away from the traditional 'command-and-control' regulatory approach, which embraces top-down, national, uniform environmental standards" (Sheila Foster quoted in Mutz, et al, 2001: 139-161).

A lack of community-based decision-making procedures was a key trigger to the creation of the environmental justice movement. People believe that their voices and concerns were not being heard by public officials and corporations. The idea of a grass roots, local, communitybased movement that gave people a voice and a forum to participate in the discussion of these decisions was a major step in combating distributive injustice. Addressing environmental issues on a local level allows for greater participation fostering a discussion for the concerns and interests of local people to be properly addressed and represented. Taking this one step further it is possible to argue that justice on any level requires that all parties involved have access to knowledge of the situation and a way to voice concerns and grievances. Without the existence of an equal procedural process, engagement and knowledge being available true justice is really never possible as one side will always have a clear advantage to influence the outcome.

A long history of environmental movements and social resistance exists in the Appalachian region. Conflicts over coal mining, mountain top removal and water and air pollution from industrial production have deep roots throughout Appalachia. Social disobedience has been a major tool to combat what Gaventa refers to as an unfair balance of power between local communities and corporations (Gaventa, 1982). Grassroots organizations developed throughout the region and the founding of the Highlander School gave a major boost 
to social organizing and resistance (Glen, 1993). Yellow Creek in Kentucky provides an example of this social mobilization, in which local residents organized to protest environmental exploitation from a chemical company (Cable, 1993). Similarly, resistance to the process of mountain top removal has been extremely fierce in the region, with people taking to picket lines and sabotaging mining equipment, as a means of protecting their homes and livelihoods (Allen, 1993). This social organizing and resistance becomes a necessary means when no procedure exists for the voicing of local concerns, or when those local concerns are blatantly over looked by the state, favoring instead corporate interests.

Procedural Justice thus relates to the relations of power that exist within society and the idea that state actors and large corporations often have access to large amounts of resources such as information, money and political figures and have a clear advantage in influencing the outcome. In relationship most people lack the money, information and political connections to provide an equal counter argument and thus face a major disadvantage in their pursuit of justice. This is what is argued by Christopher Foreman when he claims that the "real concerns of environmental justice advocates lie in the eternal yearnings for a more democratic and egalitarian society comprised of livable communities.” (Christopher Foreman quoted in Bryner, 2001: 45)

\section{Methods}

In this section, I review the methodology of discourse analysis as well as describe my methods for data collection and my analytical framework. I have designed my research to employ both archival research of newspapers and also semi-structured interviews. Using these methods jointly, helped to better inform me as a researcher and allowed for a more rounded analysis of the information being gathered. Each approach is further explained in the sections 
below, including data sources, coding structure, interview questions, interview location and coding of interview transcriptions.

Discourse analysis was developed by French philosopher Michel Foucault and is a unique and integral part of qualitative methodology. The method examines how knowledge and power relations impact meanings, attitudes and practices (Waitt 2010, 217-240). According to Waitt “discourse analysis offers insights into how particular knowledge becomes common sense and dominant, while simultaneously silencing different interpretations of the world" (Waitt 2010, 217). Discourse analysis was conducted on both the textural data retrieved from archival research and on the transcripts from interviews with my key informants. Discourse analysis requires the researcher to maintain an open mind and disposing of any preconceptions the researcher may have about the subject matter, it also requires the researcher to be reflexive in understanding their positionality and how this may impact their findings. My positionality as an outsider to the community and not experiencing the effects of gas drilling first hand, may change the way in which I interpret the current debates and discourses taking place in the county. Furthermore my position as an outsider and from an institution of higher education, may impact the ways in which residents respond to my interview questions.

\section{a. Archival Research}

Building on the theory of accumulation by dispossession within the field of resource geography, I explore the context of natural gas resource acquisition within the region and community responses from the years 2007 to 2013. I conducted archival research examining newspaper articles and other news resources to create a timeline of events from 2005 to 2012. Looking specifically at how the boom emerged, the land grab, and its economic, environmental, 
and social impacts on the local community. To code this data I used economic, environmental, and social frameworks, and looked for mentions of these issues within each article. These frameworks were reoccurring themes that represented the major ways in which the gas industry was being discussed on a local level. While archival research is challenging and presents a number of issues such as time limitations, sorting through fragmented data and in interpreting the results, it is also extremely valuable to the development of the historical narrative surrounding the process of dispossession. By examining history, a deeper and more complete analysis can be conducted (Roche 2010, 173-188). By reconstructing the historical timeline, key insights can be made into the current discourses occurring in the county and the origins of these discourses. Without examining the ways in which the land grab took place in Bradford County, a major piece of the story would be missing from the analysis. The historical perspective allows for a deeper understanding and analysis of the current discourses and debates taking place. Examining the land grab as the starting point, reframes the debates from the issues of resource extraction to the issue of resource control. This knowledge also provides a deeper understanding into the way in which the community responds to these changes and the perceptions community members have in regards to natural gas drilling. The feeling that residents have lost control becomes justified in the context that residents are no longer in control of the resource, which has led to a loss of control in other aspects of community life, including politics and social problems.

The data used for this analysis is derived from two different approaches of data collection, archival research and interviews with key informants. The first method of data collection was archival research focused on the local newspaper The Daily Review, based in Towanda Pennsylvania, regional newspapers such as The Sun Times in Williamsport Pennsylvania, the closest and largest city to Bradford County, national news sources such as The 
New York Times and CNN, and international reporting such as the BBC. I acquired newspaper articles pertaining to natural gas extraction in Bradford County by conducting queries of local and regional newspaper databases searching for specific words such as Bradford County, natural gas, economy, fracking, environment, hydraulic fracturing, jobs, gas drilling, Marcellus shale and combinations of these terms, such as Marcellus Shale in Bradford County or environmental impact of gas drilling in Bradford County. In addition, general Google queries also returned articles from other newspapers and news agencies about general information on hydraulic fracturing or regional economic development. From the 100 articles obtained, I focused on ones specifically relating to Bradford County, or outlined specific environmental, economic, or social issues that related to the entire gas drilling industry. I also located newspaper articles on resource acquisition in Bradford County using the LexisNexis Academic service which allows users to search all available publications, from local to international, using keywords designated by the user. In addition to newspaper articles LexisNexis also returned a number of brief publications surrounding the natural gas industry that were published in state reports and oil and gas quarterly's. These were incorporated as they related to specific mentions of natural gas assessments or drilling in Bradford County Pennsylvania.

Once the textual data were retrieved I organized it in chronological order and then coded the data into three categories-Economic, Environmental, and Social. Using the technique of coding allowed for the articles to be broken down into more manageable pieces that could then be utilized to tell a narrative surrounding the issues being discussed. While coding allows for the breakdown of data into smaller and more manageable pieces based on commonality along thematic lines, it also helps to show patterns that exist within that data. At the same time, coding 
can be extremely challenging in deciding how to categorize the data into meaningful clusters and hierarchies (Hay, 2010). During my analysis I looked for specific topics that related to the three categories I had created for my coding structure. The economic category looked for specific topics in relation to jobs, growth, development, income, business, and money. The environmental category focused on topics of pollution, environmental damage, habitat destruction, contamination, water usage, drinking water issues, and general destruction of the aesthetic appeal of the environment. The social category focused on mentions of crime, rent, homelessness, stress on services, traffic, and other general discontents arising. While the environmental and economic categories were straight forward in their designations, the social category presented some problems in identifying what is considered a social problem or issue. Economic, environmental and social, categories had a heavy presence in the debate surrounding the natural gas industry and were key issues to study in relation to answering my research questions, specifically the benefits and consequences of natural gas drilling. The research also helped to inform the way in which the land grab took place in the region.

After all of the articles had been coded, I initially approached the study as building a timeline, of the natural gas resource grab. After organizing the articles by year I examined the frequency at which each category was mentioned in that given year. The following chart (Table 1) represents a breakdown of articles by category and year and at the bottom each category is totaled to show the overall prevalence of each debate. In many cases, newspaper articles mentioned all three issues of the debate simultaneously, discussing economics, the environment and social problems as they related to each other and comparing the impacts each had and their effects. In many instances economics was contrasted through environmental concerns and these 
two pieces had a high prevalence of occurring together in articles. Likewise social issues also appeared with mentions of the economic impacts taking place in the region. While each of these categories stands on their own, there is a lot of interconnection between the three, something that was quite interesting when examining the articles and was really telling about the complex nature of the natural gas boom taking place in the region.

\section{b. Key Informant Interviews}

The second method employed in gathering research was the conducting of key informant interviews ${ }^{2}$ in Towanda, Pennsylvania, the county seat of Bradford County. Using information I had gathered from newspaper articles I created a list of possible key informants to interview based on agencies and people that were frequently quoted. I also used my analysis of the newspaper data to help develop my interview questions. A key informant is someone that "possesses the expertise to liaise between the researcher and the communities being researched" (Hay 2010: 109). In November, 2012, I travelled to Towanda, Pennsylvania and spent three days conducting key informant interviews with local community members. All five of the informants were female and were employed in Bradford County and all respondents with the exception of one, were current residents of the county. One informant that was not a resident had just recently moved to a neighboring county, yet remained employed in the region. Three of my informants were leasing to the gas industry, one was a large landowner, while two owned smaller properties. The two other informants were not leasing to the gas industry. One of my informants worked

\footnotetext{
${ }^{2}$ I received IRB (Institutional Review Board) approval to conduct this research. As mandated by the IRB, I explained the purpose of my research to the informant, answered any questions they may have had and gained their consent for the recording of the interview. It was also ensured to all participants that any and all information would be kept private and confidential to the extent that the law allows and that the identities of my informants would also be kept confidential.
} 
specifically with processing gas leases, one worked in a county service agency, one was involved with an advocacy group, one worked in education, and one worked with the county development agency. Each of these respondents had encounters with the gas industry but from very different perspectives. By interviewing both people that were leasing to the industry and people that were not, I received both perspectives of the gas industry. The people that are leasing directly benefit from the industry which may skew their perspective. People that are not leasing to the industry are not directly receiving benefits from the industry, yet are still being burdened by the presence of the gas industry. Conducting interviews with both populations allowed for a more rounded understanding of the impact of the gas industry.

One of the central reasons for conducting interviews was not only because of the rich information that can be obtained, but also gain a deeper and more nuanced perspective to the data that was collected from the archival research. My informants were able to elaborate and expand on many of the concepts and themes that I had uncovered in my archival research while also providing their own context and reality to the situation. The interviews I conducted were semi-structured interviews in that the questions had a "predetermined order", offering me "flexibility with regard to position/timing of questions" (Hay 2010, 387). The questions that were asked of my key informants were content focused and based on previous research that had been conducted and topics that had been uncovered, crime, traffic, job growth, well contamination, etc. Each interview lasted for around one hour, with the longest being an hour and a half and the shortest being forty-five minutes and were conducted in private. The following represents a sample of some of the interview questions that were posed to my key informants: 
œ How has natural gas changed Bradford County in the last 5 years?

œ What do you believe has caused the current boom in the natural gas industry?

\& Do you think that these changes will have a lasting impact on the region?

\& How have you responded to these changes?

$\propto$ Do you feel a loss of control in the region?

$œ$ Is there a political process for you to air your concerns?

Because the interviews were semi-structured it enabled me to pursue some follow-up questions depending on the responses given and also the general direction of the conversation. Some informants were more versed in specific areas, such as leasing, agency resources, and housing advocacy, and thus the discussion may have more heavily focused on one aspect over another. I often encouraged informants to "go off topic" as I was genuinely curious how people interpret the changes taking place around them. This led to some very interesting insights regarding such things as bar fights, homelessness, and other seemingly "unrelated" aspects of the natural gas boom. Some of my most important findings came in these moments and led me to consider social fracturing as a key element of the natural gas boom. There were many feelings, emotions and sentiments that I uncovered in my interviews that cannot be read in a newspaper article. Collecting this diversity of meanings, opinions and experiences as well as filling gaps in knowledge enhanced my findings considerably (Hay 2010: 102). Throughout my interviews I gained even more knowledge and insight into the subject matter and continually uncovered new information on aspects which I had previously felt I fully understood; even forcing me to reinterpret my analysis of the archival data.

In analyzing my interviews I took two approaches, the first was using notes that I had taken during my interviews to help in looking for specific themes, and the second was in transcribing verbatim my audio-recording of the interviews and then analyzing the text to look for reoccurring themes between my informants. These focused on the economic benefits and 
social issues that my informants continually mentioned throughout their interviews. While this was not surprising considering the use of a semi-structured interview, what was interesting was how the informants expressed these viewpoints. After completion of the transcription I conducted content analysis to look for themes, categories or patterns that emerged in the data (Dunn 2010: 124). These themes and patterns were then used in writing up the interview section of my thesis. I followed the same timeline that had been created from the archival research, specifically looking at the economic impacts, environmental issues and finally social problems. The write-up includes direct quotes from my interviews, creating a storyline that follows a similar pattern that emerged from my archival research. In recording the interviews, I was able to return to specific parts of the interview while completing my write-up, along with having a transcription in which to pull pieces from the text. The transcript represents a written reproduction of the formal interview and allows for a more complete and in-depth analysis of the data collected.

A challenge that I encountered while conducting my interviews was that many of my informants only felt comfortable speaking about particular issues and focused a lot of their attention on that particular issue. While this provided a wealth of detail and information, it was sometimes hard to broach new issues and subjects. Many of my informants also seemed to be reluctant to speak for the community and attempted to maintain a balance between their personal opinions and the broader opinion of the community. I also noticed that in the beginning of the interviews my informants were somewhat nervous and reserved in their opinions, yet as the interviews progressed they began to open up, providing stronger opinions and assessments in answering my questions. Towanda, $\mathrm{Pa}$, the site of my interviews, is a small rural town which created an insider-outsider dichotomy between me and my informants. The extent to which my 
positionality as an outsider to the community influenced the data I collected is hard to say and I think the length of the interview helped to counter this effect.

\section{The Natural Gas Grab: A Case Study of Bradford County Pennsylvania}

In the last five years, Bradford County has been transformed from a sleepy farming community into the most developed area for natural gas in the Appalachian region. Today, Bradford County boasts the most gas wells drilled in the state of Pennsylvania, with over one thousand wells producing, drilled or permitted (PA DEP, 2012). Prior to 2008, it would have been hard to imagine that this county, situated in northern Pennsylvania, along the New York border, would become the heart of the drilling industry. Today it stands as both a story of success and caution to other gas rich regions throughout the state and country. The significance of Bradford County in understanding the resource grab across the Marcellus Shale region cannot be understated. Bradford County is described as "one of the most fracked places on the planet" (Marshall, 2011). This section reconstructs the history of the resource grab that has taken place in the county, examining leasing procedures, early gas plays, price wars, and the ultimate accumulation of land from local owners into the hands of corporations. Using data gathered from both archival research and interviews conducted with key informants in the town of Towanda, I argue that the resource grab that has taken place offers a clear example of accumulation by dispossession as laid out by David Harvey.

The Marcellus shale formation is a layer of shale gas that covers an immense part of the north east United States, including states such as: New York, Ohio, West Virginia, Maryland and Pennsylvania. The vast majority of this shale gas lies under Pennsylvania, with some of the thickest formations found in the northern part of the state. The existence of this shale gas has 
been known since the 1980s, when the United States Geological Survey confirmed its existence. Yet, at a depth between 5,000-7,000 feet and due to meager estimates for the potential of recoverable gas, drilling for shale gas was largely overlooked as unprofitable (Gill, 2012). This began to change with new drilling techniques, specifically horizontal drilling and hydraulic fracturing, as well as rising natural gas prices.

Drilling in the Marcellus Shale uses the technique of horizontal drilling in which drills reach the depth of the gas and then turn horizontally and continue to drill along the length of the shale ( See Figure 4). After the drilling process is completed a technique known as hydraulic fracturing is used in which large amounts of water, sand and other chemicals are pumped into the well under high pressure. This causes the pores of the rocks to be cracked and allows more gas to be released, thus making unconventional shale plays possible (EPA, 2010, Geology, 2013). These techniques which were largely proven in the Barnet shale in Texas would ultimately be transferred to the region and make drilling in the Marcellus shale a profitable venture. In 2004 Range Resources drilled the first successful well into the Marcellus formation and were encouraged by the results of how much gas was able to be retrieved. Still the idea of a gas boom in the county seemed implausible and no one really knew how much gas was in the Marcellus and how much could be retrieved.

Bradford County is a rural community, consisting of small towns surrounded by farms and forest, in a region of Pennsylvania known as the endless mountains( See Figure 2). The major economic activity in the county is farming and historically farmers and other large landowners have leased their mineral rights to the oil and gas industry. It was in essence a common practice that had been done for many years for small amounts of money that farmers 
would then use to pay property taxes or other bills. Jill ${ }^{3}$, one of my key informants whose farm had been in her family for many generations explained to me the historical interaction between farmers and leasing. "Farmers always had these leases cause they had large tracts of land the general public didn't have them, people with large land had them but they didn't really get any money from it" (Jill, Personal Communication, 2012). The average rate was around five dollars per acre and the farmers land was rarely, if ever impacted by any drilling coming to fruition. All of that was about to change as one of the largest land grabs in the country began to be played out.

According to Sandra, a staffer at the county clerk's office, in 2006 a silent wave of leasing was taking place as companies began searching deeds and seeking out landowners to sign leases, as her sentiments suggests: "I think that we started about 2006 is when we had Anadarko who came in and they kind of swept the county and that's when it was starting out, with small leases being filed" (Sandra, Personal Communication 2012). According to its website, "Anadarko is among the largest independent oil and natural gas exploration and production companies in the world..... the company's portfolio of assets encompasses premier positions in U.S. onshore shale's and resources plays in.....the Appalachian Basin" (Anadarko Petroleum Corporation, 2012). The company currently holds 260,000 net acres of land in North-central Pennsylvania, including land in Bradford County. The large scale acquisition of mineral rights and leases requires a juggernaut of lawyers, researchers and landmen working together to bring a region under the control of their respective corporations. This is usually done behind the scenes, as companies work to gain the most land possible for the cheapest price, as Jill noted:

\footnotetext{
${ }^{3}$ Pseudonyms are used to protect the identity of all interviewees.
} 
"The first thing I saw changing was the landmen coming in and starting to reside in hotels and the reason I even became aware of that is because we handle the notary applications and they would become notaries in order to notarize the leases ...that was the first time that I was aware it was picking up and these people were definitely not from the area and using the hotel address in order to obtain a notary. I think it kind of eased in, I would say that was between 2007 and 2008" (Jill, Personal Communication, 2012).

In 2008, data from a professor at Penn State University was released, claiming the Marcellus shale could hold as much as 500 trillion cubic feet of natural gas and that 50 trillion cubic feet could be retrievable. This finding thrust Marcellus Shale into the national headlines and put places like Bradford County and Towanda on the map. What had started as a small leasing effort turned into frenzy as major energy companies from around the county descended on the region to secure land for drilling and become a part of the play. What ensued was a price war as companies began competing with one another for access to the most profitable land. The majority of the resource in the play is located in Pennsylvania and some of the most profitable gas plays are directly under Bradford County, which sits atop some of the thickest and richest deposits of the Marcellus Shale. The Pittsburgh Tribune reported "PA. Atop Natural Gas Mother Lode" which outlined the major implications gas drilling could have on communities throughout the state (Stouffer, 2008). By 2008, three companies: Atlas Energy Resources, Rex Energy Corp, and Range Resources, had control over more than 600,000 acres of land in the Marcellus Shale play (Stouffer, 2008). During the first two months of 2008, Elexco Land Co. filed more than 60 leases at the county courthouse. The race for control was underway, with one newspaper 
ad by Elexco reading "we will be signing leases that guarantee you at least $\$ 2,000$ per acre" (Lowenstein, 2008).

The promise of $\$ 2,000$ dollars an acre was an economic windfall for local property owners in an economically depressed region that hadn't seen much investment or growth for years. Farmers with large tracts of land were especially intrigued by the rise in leasing rates, at least the ones whose lands weren't already locked in to a prior lease. Leasing became the hot topic. In October of 2008, there were eight newspaper articles discussing the economic benefits of leasing, along with advertising for leasing events and seminars to educate the public on negotiating a good lease. Even though leasing efforts were present in the area for many years, 2008 represented a fundamental shift in the efforts of companies to bring the region under their control, not just large land holders, but small property owners as well. The CEO of Cabot Oil \& Gas, Dan Dinges is quoted as saying “the lease activity that is going on and the land grab we're seeing out there is basically unprecedented" (Spencer, May 2008). In Bradford County from 2006 to 2007 there were 2,839 new gas leases signed (Lowenstein, 2008). By October of 2008 however there were 3,644 new gas leases already signed in the county Chesapeake Appalachia alone had signed 2,018 leases in 2008 alone, representing tens of thousands of acres in the county. Gaining access to the land and resources has to occur before a drilling rig ever bores a single hole and a leasing war between companies emerged, as each company vied for control over the land. Indeed, even with the number of leases signed "actual drilling in the Marcellus Shale in Bradford County [was] still in the early stages" (Lowenstein, Oct. 2008).

This frenzy for control, more than demand for natural gas, fueled the boom in Bradford County. While landmen pitched stories of helping to provide energy independence for America, 
the reality of the situation is strikingly different. Natural gas leasing is more similar to the real estate market, where gas companies earn their profit not only from selling natural gas, but from getting control over the resource and then selling that control for a profit. Chesapeake Energy, the largest leaseholder of natural gas in the United States, has made a fortune doing exactly that, signing leases and then selling them, or by selling the future production of the well. Goodell, a reporter from Rolling Stone Magazine, describes this as a "Fracking Bubble" similar to the real estate bubble that burst in 2008 and plunged the country into a depression (Goodell, 2011). The resource grab, not the gas itself, is the real story. "McClendon (CEO of Chesapeake Energy) has financed this land grab with junk bonds and complex partnerships and future production deals, creating a highly leveraged, deeply indebted company that has more in common with Enron than ExxonMobil" (Goodell 2011). The hype surrounding Marcellus Shale drove investors to sink billions of dollars into the industry, and companies gained the much needed cash to secure more land and finance their drilling activities. In fact companies such as Chesapeake Energy are extremely proud of their speculative accomplishment. "We won what we have called the gas shale land grab. We believed that by winning this land grab, we could establish Chesapeake as the premier U.S. natural gas producer for decades to come" (Chesapeake Energy Corporation, 2012).

\section{Community Responses}

Residents in Bradford County responded to the natural gas resource grab in multifaceted ways. Using data collected from archival research and key informant interviews, I explore five community responses associated with resource grabbing: speculative economic benefits, leasing labyrinths, ambivalent environmentalism, social fracturing, and power dynamics. Each of these 
responses captures how local residents perceive and rationalize the impacts of resource extraction in their personal lives and in the county. These local voices and perspectives are important in understanding the complex ways residents experience impacts upon their local community. These debates shape the ways in which natural gas drilling is perceived and how local residents rationalize the positive and negative impacts of the industry. This rationalization plays a major role in how the gas industry has been able to develop in the county and is a mix of a speculation of hopes and dreams and a reality of consequences.

\section{a. Speculative Economic Benefits}

Speculative economic discourses permeate every aspect of the natural gas boom.

Whether talking about the negotiation of leases, jobs, increased business, or development in the county, the discussion of economic growth is one of the most common. During my archival research and key informant interviews, speculation about a better economic future was a common reoccurring thread, used to describe and explain the ways in which the natural gas boom was impacting the region. The speculative economic windfall proposed by Marcellus

Shale in Bradford County has received large amounts of attention at the county level and among its residents. This discourse, however, is centered on short term gains, and is rooted in dreams about the industry and hopes for the future. While gas companies have made promises to local residents about the long term economic benefits gas drilling will have on the county, the future remains uncertain. Much of this speculation comes from the presumed production of a gas well over the course of its life, how much gas is produced and the price at which that gas can be sold, both of which influence the amount of drilling taking place and the amount residents receive in royalties. 
According to both news sources and interviews one of the most significant economic changes triggered by the natural gas boom has been "a transition from an agrarian based economy to an industrial based one" (Hrin, 2008). The boom brought good paying jobs, low unemployment, increased revenue to local business, investment in new infrastructure, and the establishment of new businesses. While the rest of the state and country suffered through a major recession that began in 2007, Bradford County had one of the lowest unemployment rates in the state and posted economic growth while many other counties were suffering job losses. Doug McLinko one of the county commissioners, claimed" the recession that hit the rest of the country passed right over us" (Hicks, 2012 ). The fact that Bradford County experienced economic growth, while the rest of the country stagnated, created a powerful sentiment that the gas industry was a savior, protecting the region from decline. In many ways the resource grab itself represented an economic windfall to property owners who earned revenue from leasing their land and royalties once drilling occurred. In a sense for some, they were earning something for doing nothing.

Another perceived economic benefit of the gas boom is the increased revenue to both local business and the county in general. Lisa a key informant noted: "well it certainly has brought money into the area.... and not only with all those people that have benefitted from having gas wells on their properties and they have gained money from that and then also with all these people being here it has boosted our economy" (Lisa, Personal Communication, 2012). The influx in population has created a boom to local business owners and renters which residents view as being a positive impact on the community as a whole. Even the county was able to increase its revenue through both the leasing of county land and through the fees for the filing of 
leases. In 2011, the state enacted an impact fee on natural gas and Bradford County alone received more than eight million dollars. This has allowed the county to keep taxes low while at the same time investing in the repair of buildings and new infrastructure in the county.

Residents also noted a general increase in investment taking place in the county, as gas companies began to drill new wells, build new infrastructure and establish support services. There was also increased investment coming in from outside of the gas companies as new hotels were built to house the influx of workers coming into the region. Joyce, one of my informants explained, they have built at least 6 hotels in the county now where before we only had one or two in the county" (Joyce, Personal Communication, 2012). Local businesses also expanded, and entirely new businesses sprang up to serve the needs of the gas industry. "A local business like Hurley's grocery store has been able to expand to having a catering service. And they are actually serving the housing facility, the residential facility for Chesapeake. We call it 'man camp' but that's not the politically correct terminology, and they cater to it" (Jill, Personal Communication, 2012). These 'man camps' are built to house the large influx of gas workers coming in from other parts of the country to work in the gas industry in Bradford County. Many of the rig hands, or what locals refer to as rough necks, come from other shale plays in Oklahoma and Texas because they have experience and training in working on the rigs.

An important aspect of the economic discourse in Bradford County centered on job creation, specifically on well-paying jobs being brought into the county. The majority of people in the county worked in farming or service and making a living was a challenge. With increased labor demand in the gas industry, wages became extremely competitive. The perception among local residents is that the natural gas boom generated job growth. "It has brought a lot of 
revenue into the towns a lot of jobs, it has created jobs for truck drivers, I think a lot of people have quit their jobs knowing that they could double their wages working for the gas company" (Sandra, Personal Communication, 2012). Employment, however, was uneven with only a certain segment of the population able to obtain higher paying jobs. As mentioned earlier many of the jobs went to people outside of the community, brought in by the corporations to work on the rigs. Those unable to secure a job in the gas industry were left to continue to work in minimum pay positions. "It brought a certain amount of jobs and created some industries that certain individuals within the community could take advantage of. But there is always going to be the need for someone that works at McDonald's and at the mini mart, and someone who works at the grocery store. Those types of jobs are not high paying jobs" (Joyce, Personal Communication, 2012). A large proportion of the jobs created by the gas industry are in fact going to people outside of the region further limiting the benefit to local residents. Local residents, however, have been able to capitalize by offering services such as cleaning and laundry to gas workers. However, there is still an inequality in these benefits, only a certain percentage of the population was in a position to capitalize on these new markets. Specifically the ones that capitalized were people that were in a financial position to invest money in the creation of these new businesses. "I would say it's probably $75-25,25 \%$ of the people have benefitted from it" (Jill, Personal Communication, 2012).

While discussions of economic change were often framed in terms of positive effects for the residents, talk of economic inequality was also present when explaining inequalities between those who could capitalize on the resource grab and those who were left out. Although some economic benefit has been gained by a small percentage of the population, the long term 
economic benefits to the county and its residents are unclear. No one really knows what the future of the gas industry will bring in terms of economic benefits; the entire industry in the region has been built on the speculation of high gas prices and high amounts of retrievable natural gas. Likewise, the arguments for drilling have centered on the speculation of long-term economic benefits the industry will bring to the region. These benefits have not been evenly distributed throughout the community as the promises of high paying jobs; large royalty checks and a boom in business have only been realized by a small stratum of the population and the long term outcome remains unclear. In recent years (2011-2013), the price of natural gas has continually fallen because of mild winters and an oversupply of the resource from increased drilling activity. During my time in Bradford County, many of my informants discussed the slowdown in the industry as rigs moved to other locations to extract more valuable liquid gas. One of my key informants even discussed how her son and former co-worker had recently been laid off as a result of the slowdown and she expressed hope that the gas industry would return and that the well-paying jobs would be permanent (Sandra, Personal Communication, 2012).

Speculative economic benefits play an important role in how local residents view the impacts of the gas industry and while the majority sees these impacts as good, there is a clear distributive injustice in access to these opportunities. A major problem lies in the distribution of these perceived economic benefits: the resource grab that took place in the county is discussed in terms of the economic benefits it will bring to property owners and the local community. Surprisingly no discussion occurs during the leasing boom, about the uneven distribution of economic benefits, instead there is a speculation that all members of the community will eventually benefit though leasing payments, well-paying jobs, or increased business. However, 
the reality of the situation is quite different as not all residents have been able to capitalize on the economic benefits brought by the natural gas industry. The economic discourse follows a belief in a top down economic benefit system in which eventually everyone in the community will benefit from the increased revenue being brought into the region. This argument is made by local officials and representatives of the gas industry. Residents who owned land or business were in a favorable position to benefit from the gas industry. Likewise, the county has benefitted from the increased revenue being collected in the form of increased tax revenue, the leasing of county lands or most recently through an impact fee on natural gas companies. The population that was unable to capitalize on the industry has been left out and has seen an exacerbation of economic inequality. This inequality not only exists between landowners and non-land-owners, or residents and outsiders, but also among landowners themselves.

\section{b. Leasing Labyrinths and Unjust Distribution of Benefits}

Leasing represents the major vehicle in which control of the resource moves from the private hands of the landowner into the hands of others. The leasing process is a complex set of legal contracts between the landowner and the gas company. These leasing arrangements transfer control from individual property owners to gas companies. However, the process by which capital investment in resource control occurs is often quite mysterious to residents and scholars alike. In the process of lease negotiation, private landowners rarely hold a powerful position regarding market information or other critical knowledge. As one of my informants explained, the benefits from resource acquisition was uneven with some private landowners gaining more than others and potential earnings rising over time. 
So they (in reference to Annandarko, Chesapeake and Chief Exploration) were the three main gas companies doing the leasing. A lot of people were only being paid between 30 and 35 dollars an acre in 2006. As time went on people weren't aware. They thought that was a lot of money. As time went on activity was coming in more aggressively and more companies were coming in and they started raising the price per acre. They were going up to $\$ 1500$. Me myself I own two acres and we got paid I believe $\$ 1200$ dollars per acre. After a few years it got up to between $\$ 5500$ and $\$ 6000$ dollars per acre (Sandra, Personal Communication 2012).

In many cases, large discrepancies existed between landowners with some garnering large checks and others receiving small amounts. As Jill, another informant described, she signed a lease before the major interests in the Marcellus developed. "Our neighbor got 2500 dollars an acre; I got 5 dollars an acre" (Jill, Personal Communication, 2012). This discrepancy in leasing amounts created tension and anger between neighbors.

Some people have earned a lot from leases and there are other people that are angry because they aren't getting anything. You know nobody is approaching them. They say why are you getting all kinds of money and were not getting anything (Lisa, Personal Communication, 2012).

As these comments illustrate, the economic gains of leasing were uneven. While some were successful in garnering large amounts of money for their properties, others had already been locked into leases that only granted small amounts of money per acre. Many residents, my informants explained, simply quiesced with companies and the situation, taking no recourse. Jill recounted a story to me of "just keeping quiet" in hopes of riding out her current lease and then renegotiating for better terms. However, many leases were designed with automatic renewal clauses. When Jill's lease was about to expire she received a check and letter in the mail, stating that her lease would be renewed at the already negotiated rate of five dollars an acre. She felt powerless to challenge. 
I asked one land owner if she felt like she had lost control of her land "well you have basically because you signed a right away to let them there. According to the lease documents you have to give them access to the gas well. So if there is a gas well on you or on your neighbors (land) or whatever, you do have to allow them access: (Jill, Personal Communication 2012) Not only do the leases require access be granted to the gas companies at all times, they also are written in such a manner as to lock the land owners into them. "Well we have had ours for so long and we read it and read it and my husband was looking for loopholes but there aren't any in their cause their lawyers are really good at writing them" (Jill, Personal Communication, 2012). While it can be argued that the landowners signing the lease agreed to the terms and conditions presented, many people did not fully understand the leases they were signing and the impact the gas drilling industry would come to have upon the land and the community.

A lot of seniors felt like they were taken advantage of, they trusted those landmen that came and gave them the leases and then when they left they felt like they were maybe a year or so into that contract then all of a sudden they are starting to think that some things don't jive with the way it was explained to me and then they are starting to feel angry that they were taken advantage of and I think that did happen in a lot of ways because this county has been nose to the grind stone kind of people just eking out a living not really maybe paying attention and besides this is in Texas and it's just so far removed, why would you be up on it, so I think that they were not prepared with education and I think that we are still a very trusting environment that didn't see red flags maybe didn't question things as they came just accepted without question and I think that was a detriment to this county because of that (Joyce, Personal Communication, 2012).

Beyond the broken promises given to local residents by the landmen and companies, there were other legal strategies employed by the gas companies to exert control over land through a legal framework. One of the processes was the idea of "uniting" leases. The idea behind uniting stems back to horizontal drilling, in which one well can be drilled to cross multiple properties and drill large areas of gas from the same well pad. In one example a 
resident had leased 141 acres of his property to a gas company, yet only 22.5 of those acres were in a unit (See Appendix A). This would mean that the landowner will only be getting paid royalties on those 22.5 acres, but the gas company exerts control over the entire lease because some production is occurring. A local employee at the courthouse explained the terms of unit leasing to me like this:

Some are for 5 years some are 10 years, but once [landowners] get into a pooling or a unit, even though that lease is getting ready to expire, that draws them into the declaration of the unit. So then...they don't get to renew. A lot of people thought once their lease gets to the end of their term they could renegotiate. But once they are into a unit...they can't go back and negotiate for those thousands of dollars on a lease like other people have before (Sandra, Personal Communication, 2012).

In essence, through an act of spatial manipulation, the landowner's pre-existing lease can be remapped and locked into the terms of a new lease as long as that unit is continuing to produce. This effectively secures the resource in the hands of natural gas companies indefinitely.

One of the major engines of capital accumulation for natural gas companies is the selling and re-leasing of lands under their control to other energy companies. In one example from the county clerk's office, I was shown how an individual's property was re-leased five times to different gas companies. Each will then gain control of a percentage of the original lease. Through this process of subdivision, control over land confuses residents further as multiple gas companies own shares in leases throughout the county. "We have documents assigned numerous times. We have so many different companies that they will take a lease and sign interest to another company to another company. It's just like a chain; you might be tied on with 5 or 6 different gas companies, even though you signed up with one" (Sandra, Personal Communication, 2012). This only further complicates the problem of taking action as a 
landowner, because many people are unsure as to who owns their gas lease and who has control over their resources.

\section{c. Ambivalent Environmentalism}

“Forty-years from now we might look back and say 'What the hell did we do?' Or maybe not. Life's a gamble" (Hall, 2011).

Much like the economic discourse discussed above, the arguments surrounding environmental concerns are built upon speculation of possible outcomes and fear. The blowout in 2011 sounded alarms throughout the environmental community as national media reported on the event and people began to wonder about the possible environmental impacts. The blowout resulted in the contamination of a pasture and local stream; the broader impacts of the industry on the environment have yet to be seen. Bradford County has not turned into an industrial waste land or a Sodom and Gomorrah of raining fire and brimstone, my informants explained how there is still the natural beauty of farmlands, forests and mountain vistas. While the media swirls concern about the dangers of fracking fluids and the possibility of ground water infiltration, my key informants remained rather optimistic about the potential negative environmental impacts that may occur. Residents were willing to accept the possible environmental outcomes in return for the possible economic benefits. Currently potential economic benefits are outweighing the potential environmental impacts. No major studies have been conducted in understanding the broader impact the gas industry may have on the environment, so residents remain hopeful and optimistic. In a sense they have not bought in to the environmental speculation that is occurring, because at present they see no evidence of it occurring. 
Residents of Bradford County view the environmental impacts of resource extraction in context of the rural nature of the county and what they view as being most important to their everyday lives. Natural gas drilling presents a multitude of potential environmental impacts that people in Bradford County either perceive through the media or through personal contact with environmental hazards. While some residents experience these impacts more than others, they were aware that gas drilling has changed the environment, by referring to gas rigs, pipelines or other footprints of the industry on the landscape. Some residents argue that the industry has not had any adverse effects on the natural environment, while others argue that the industry is contaminating ground water, causing habitat destruction, and polluting land and streams. The discussion of the environment is controversial.

The 2011 blowout in Bradford County opened a broader national dialogue about the environmental concerns regarding the safety and impacts of hydraulic fracturing. After the blowout a new conversation began to emerge, in which residents began to question the safety of the drilling process and its non-economic impact on their everyday lives. Environmental concerns are represented most strongly in relation to the shift from an agrarian to industrial landscape. Local Newspapers frequently detailed the impact natural gas drilling was having on residents that have leased their land. Residents describe being unable to use their well water and forced to truck water into their homes and store it in water buffalos, large holding tanks placed outside of homes to provide clean water (Swift, 2011). Other residents describe the damage to their fields and pastures through chemical or fracking fluid spills that rendered that land unuseable. Finally some residents also discuss the scar that the gas industry has left on the landscape, clearing large patches of forest to build roads, drilling sites, well pads and pipelines. 
"We no longer have the Endless Mountains beauty anymore, it's forever lost" (Lowenstein, 2010). These environmental negatives however, are not evenly distributed throughout the population, as drinking water contamination occurs to residents that rely on wells to obtain their drinking water (Lowenstein, 2011). Likewise, chemical spills are much more likely to occur on residents properties that host the drill pad and only certain land is needed for the construction of pipelines.

There is also the presence of a discourse of catastrophe. National media attention thrust the environmental dangers into the public perception. "It was the onshore, natural gas version of what happened to BP in the Gulf two years ago" (Goodell, 2011). Prior to this event, environmental concerns had been viewed as largely unfounded or unproven; people complained about changes in their water or foul odors. Yet, scientific studies on this issue were sparse and industry spokesmen as well as politicians claimed that hydraulic fracturing was a safe technique. According to one environmental group active in other shale plays, "Drilling will lead to contaminated drinking water, carcinogens in the farmland and food chain, torn-up roads, risk of explosions, toxic air pollution, plummeting real estate values and screeching noise pollution" (Brubaker, 2008).

While considerable discussion in local newspapers focused on the environmental impacts of natural gas drilling as being negative, I was surprised to find that during my interviews it was not a major topic of discussion. My informants described certain changes in the environment, yet they did not passionately claim that a major environmental impact was occurring. In fact my informants seemed ambivalent when viewing potential environmental damage. "For now it is a lot of destruction and taking down a lot of trees and doing a lot of stuff in order to put these pads 
in that eventually will years and years from now grow back up and there will only be that little pad"(Lisa, Personal Communication, 2012). There was also a speculation and hope that everything would be okay. Moreover, there were assumptions that the industry was sincere about making minimal environmental impacts. However, it was clear that my informants were not informed about the risks associated with hydraulic fracturing. Residents were cautious of what they were being told by both companies and environmental groups. Most simply judged environmental impacts based on the information that is available to them, however, they did not express it as a primary concern.

I don't think [the companies] tell you everything that's going on. I mean you can only read between the lines. Hopefully it's a good thing for the county 10 years or 20 years from now I am hoping that people are happy with what is going on. I am hoping it hasn't caused any health issues for kids now and for the environment I hope it doesn't do anything. We don't see any explosions going on in the county so no one really knows. (Sandra, Personal Communication, 2012).

A lack of credible information and considerable uncertainty seemed to temper residents' views on environmental concerns. I attribute this ambivalence, in part, to the uneven impacts associated with drilling pollution. While the blowout brought a national spotlight to the issue, and drinking water contamination has been experienced in Bradford County, these impacts occurred on private land, far removed from any towns and the vast majority of the population was unaffected. Because drilling occurs for the most part on private land the environmental impacts of natural gas drilling go largely unseen, hidden away on private property. What is a major concern to residents are the impacts that can be seen and that occur in the public space, these impacts work to fracture the social fabric of the community. 


\section{d. Social Fracturing}

"People accept loss of small town for the damn money." (Ginger, Personal Communication, 2012)

A focus on economic speculation, unjust benefit distribution and environmental ambivalence often masks a deeper reality in Bradford County; social fracturing. Social fracturing refers to a combination of inequality, disruptions to everyday life, and a conflict between insiders and outsiders. Local residents are experiencing the impact of traffic, skyrocketing crime and rent, stress on community resources, increased homelessness and an exacerbation of class dynamics. Discussions surrounding these impacts do not take place in the context of speculation or hope, but instead in the reality of what everyday life is like in the community, what local residents see, hear and experience. It is this change and these impacts that should be focused on when discussing the true impacts of natural gas. People are unable to travel as they once did, afford homes that they once rented, go to establishments that they once frequented, the social fabric of normality in everyday life is fraying as residents are forced to cope with the impacts brought about by natural gas drilling. This section explores these impacts and the ways in which residents express their concerns, frustrations and responses to dealing with this new reality.

While the natural gas wells are isolated in forested areas and farms, the effects of the natural gas industry are not restricted to these areas. The people and logistical support systems that make the natural gas industry run are highly visible in the local community. The broadbased impacts of the natural gas industry on the community, which I call a fraying of the social fabric, are threefold. First, there are frequently cited problems of traffic. Second, there is the 
problem of rowdy roughnecks "outsiders" employed in the industry who some claim have upset the social fabric. Third there are less visible problems: increased rent, stress on local resources, increased homelessness and an exacerbation of class dynamics. These problems are not experienced equally across society with marginalized residents being more heavily impacted than others. Some residents walked away with million dollar checks in leasing, other residents have been made homeless. This fact in and of itself necessitates the importance of these social impacts and the ways in which residents perceive and respond to them.

The first and most perceived impact of the natural gas industry is the amount of traffic created in the local communities. Not only was it consistently mentioned throughout my archival research, this problem was also a major impact discussed during my interviews. "The traffic in the town of Towanda can only be described as horrendous" (Lowenstein 2010). The region now has morning and afternoon rush hour and the headache it has brought to local residents. Traffic represents the most visible sign that things in the community have changed and residents took notice (See Figure 6). The amount of people in the town and the level of economic activity both increased, yet the roads had not, creating animosity among longtime residents that had seen their daily routines shattered. "Going out shopping you worked around different hours... because traffic was so heavy, on our lunch hours when we used to take lunch and go out of town, but now traffic would be backed up for almost an hour at a time, so that kind of limited your time going any place" (Sandra, Personal Communication, 2012). In Towanda it would not be unusual for traffic to back up for hours with the roads filled with trucks carrying equipment and supplies to rigs throughout the county. "Traffic would be awful I mean if you would go...route 6 out to the $\mathrm{K}$ mart plaza which is maybe a mile and a half I could do that on 
my lunch hour no problem but now I have to detour around about the hill, cause if there is traffic there is no way I am getting back here in an hour" (Joyce, Personal Communication, 2012). Local residents have been forced to cope with the consequence of increased traffic. A definite annoyance and powerlessness surrounding the situation exists.

There is a lot more traffic...just going to the store,... a lot of trucks, that's a really big pain in the butt, cause you want to go out to Mansfield and...there is really only one road to Mansfield so if you want to go instead of it being an hour from where I live it's an hour and a half cause you're going to follow a truck...if you want to go anywhere on 220 expect it to take a half hour longer cause you're going to follow trucks so you always have to anticipate where you're going there is always going to be trucks cause there is usually always water trucks on the road or some kind of, we call them gas holes, on the road (Lisa, Personal Communication, 2012).

Second, the influx in population to work in the gas industry also created a spike in crime rates recorded at both a county level and also a municipal level in Towanda. The district attorney for Bradford County said that "economic boom equals crime boom" suggesting that the increasing crime rates had a direct correlation to the influx of natural gas drillers (Needles, 2011). A study released in 2011 confirmed the large increase in crime that was accompanying the gas drilling industry in the region (See Figure 7). In Bradford County, drunken driving arrests are up more than 60 percent and in Towanda alone the arrests for DUI are up 50 percent from 2008. The increase has put stress on local police agencies to handle the amount of crimes being reported. The gas industry has also brought other challenges to the area in terms of law enforcement, including the large influx of non-English speaking people brought in from other regions to work on the rigs, for which services are extremely limited. (Needles, 2011). The increasing crime has forced the state to assign five more state police officers in Towanda, and the county has hired a third assistant district attorney, something unusual for a county with a relatively small population. 
The increased crime rates have forced residents to change their lifestyles and become much more aware of their surroundings. "You're just kind of always expecting, that stuff, you want to go to your local establishment and have a beer and you got to expect that there is going to be some kind of fight or deal with some gas holes got to talk to you and you just want them to leave you alone" (Lisa, Personal Communication, 2012). One woman I talked to about the crime told me that "people have had to be more cautious when going out because of the crime" (Ginger, Personal Communication, 2012). Another informant echoed the same concern about the crime rates saying that "there is more crime going on with DUI's there's a lot of stealing going on" (Sandra, Personal Communication, 2012). Bar fighting had been so bad in the town of Sayer that the mayor had proposed setting a curfew at midnight (Lisa, Personal Communication. 2012).

Third, the arrival of a large, well paid population of gas workers had another less visible impact upon the local community one that specifically targeted an already marginalized population. An article published by the local newspaper entitled "Skyrocketing Rent in Bradford County; Influx of Gas Workers Creating Shortage of Affordable Housing" discussed the struggles local residents were facing (Lowenstein, 2010). A study conducted in 2010 showed that rent had more than tripled for some housing (See Figure 8) and had doubled for most properties and that the eviction rate had also skyrocketed (Environment Digest, 2010). As one of my informants claimed, "housing has been an issue ...a lot of people who have rental properties have raised their rent so just making it impossible for local people to pay that amount of rent" (Lisa, Personal Communication, 2012). Lack of affordable housing put stress on the local homeless assistance program and it is unable to find vacant motel rooms for emergency cases 
because the industry has booked nearly every room in the county. Bill Farley the director of the local agency on aging was quoted in the local newspaper saying that "the potential now exist that more of our frail and low-income population will join the ranks of the homeless in rural Pennsylvania" (Lowenstein, Jan. 2010). People that occupy a marginal position within the community are most likely to bear the brunt of the negative impacts the natural gas industry has brought to the region.

A surprising social impact that I did not expect to encounter was the problem of homelessness in Bradford County. People that rent and are on fixed incomes were more likely to be made homeless by the natural gas boom. The rent increases brought on by the gas industry has even threatened to force moderate income families into poverty. As Douglass Johnston, of the Futures Community Support Services noted in a local newspaper, "rents have increased to the point where even moderate income families cannot afford housing" (Douglas Johnston, Quoted in Lowenstein, 2010).

People have a vision of what homelessness is, they envision a derelict with matted hair and three coats and brown bag with a bottle in it, sleeping on a street grate, that is not what homelessness looks like in Bradford County, it looks like people going from friend to friend couch surfing it looks like three generations in a home it looks like people camping out in the summer time under the bridge because they have no place to go its people sleeping in their cars. (Joyce, Personal Communication, 2012)

The problem of homelessness was discussed at length with some of my key informants and they expressed the importance this impact was having on people within the community. "Affordable housing now has become our biggest social issue; I would say it's basically the foundation for any of the other social problems were having" (Joyce, Personal Communication, 2012). Those unable to afford the increased rents are evicted and the majority of the properties are rented to gas drillers that are able to afford the higher rents. One of my informants expressed the burdened 
that has befallen local people that are struggling to stay in the area, even as rents continue to price them out of their homes. The increased demand in the housing market has forced more people into a marginal living position and exacerbated traditional housing issues.

The people that are coming here working on gas wells they can afford it that wasn't a big deal, unfortunately there are a lot of local people that have been forced to move to places that weren't their homes, moving out of the area or living in places that are just less than desirable because that is what they can afford. If you looked back you would see that a lot of the rent and even the prices of homes, rent has probably doubled since the start of this and even the price of homes have gone up a lot I mean tremendously since the gas industry moved in. So for people that have lived here all their lives that's really caused a lot of burden you know on people that want to stay here (Lisa, Personal Communication 2012).

People living in rental properties are experiencing negative impacts while being excluded from receiving little positive benefits. The people that are renting homes had no input into the decision to drill for gas; the leases were negotiated among private landowners. If someone in the county doesn't own land they are effectively left out of the conversation. Among my informants there was a real empathy to this matter; my informants understood that these people were being negatively affected through no fault of their own other than by being poor. My informants also understood the stress and uncertainty people in this positioned faced and one of my informants has dedicated her time to advocate for this population.

The majority of the work I am doing is in the housing and particularly those that are on the mid to lower spectrum of the culture, even those who are working people now cannot afford housing and so its displaced people that were once self-sufficient and has created more people that are at the bottom of the barrel and see no way of getting out of it. (Joyce, Personal Communication, 2012)

The gas drilling boom has exacerbated issues of class and marginality, as mentioned before some have been made millionaires, others have been made homeless. In many ways it is the uncertainty caused by the gas boom that is most stressful upon the lives of local residents as 
people are unsure what the next month may bring. "People don't want us to know they are suffering they are proud and they are ashamed, there scared like I said they see no end in sight, no how is this going to change" (Joyce, Personal Communication, 2012). That fear and shame has made it extremely hard for local agencies to track the true number of homeless people, in the first 8 months of 2012 the agency had recorded 244 people needing housing that represents $4 \%$ of the population of Bradford County (Joyce, Personal Communication 2012). This stress and suffering put on the local population has been further magnified by the lack of resources available to help members of the community as more people are in need of assistance. "We have a bigger population to deal with and the same amount of money" (Lisa, Personal Communication, 2012). The increased population has created a competition for scarce resources especially in the field of human services. This has increased the problem of delivering services to new people and has impacted the traditional population that had relied on these social services such as rent subsidies, health services and food banks, to survive. "They are people that have been down on their luck, before they had resources, but now the resources are so slim" (Jill, Personal Communication, 2012).

My informants expressed a deep concern about the social impacts the gas drilling industry was bringing to the region. These impacts hit close to home and are much more visible in the community with bar fights, traffic and homeless people. This visualization has a major influence on their perspectives. They see every day how their local community has changed and how their lives have been impacted, whether it's not being able to go to the bar, or go out for lunch, or afford a decent home, things have changed. The social impacts move and upset people because they are impacted or have friends, neighbors, clients or co-workers that are being 
negatively impacted and they see and hear their struggles. While residents don't admit it, they

have lost control over aspects of their lives and community and the discourse that is being described is that struggle to regain control.

\section{e. Power (in the) Play}

The politics of natural gas drilling in Pennsylvania is an emerging issue in Bradford County as new bills and laws are being proposed to strip away local and individual control over the resource. The power of the state is working to support the interests of gas drilling companies by passing new laws to expand the availability of land for drilling. Paradoxically this was not a major topic of discussion during my time in Bradford County. When I asked my informants about different bills proposed in the state congress (particularly House Bill 1950 and House Bill 977), all were unaware of the bills or the implications they would have upon political decisionmaking, the power of gas companies as well as the impacts on the local community and residents. My informants were unaware of the political battle taking place in the state capitol, Harrisburg, over the future of gas drilling. Bradford County residents that I interviewed in the most heavily drilled county in the state could not offer critical perspectives. The two bills, that I describe below represent a major loss of control for both local governments and individual property owners; and accelerate the unjust distribution of benefits and social fracturing currently taking place across the region.

There seems to be a scale disconnect between discussions taking place in the political arena - driven by speculative economics and the actual economic, social, and environmental impacts in gas-producing communities. Natural gas has become extremely political as the gas industry pushes to maintain its control over the resource in the face of increasing local pressures, 
as people voice their concerns over increasing crime, rents and traffic problems. In the rare instance that residents referenced politics, it tended to focus on the county commissioner scale. The commissioners set regulations at the county scale, while the governor, state senators and representatives set regulations at the larger state scale. "Two republican commissioners are a missing cog in the process. They will not even entertain the thought that we have a problem, it's all been good" (Joyce, Personal Communication, 2012). According to my informants, a divide exists between members of the community that view gas drilling as a problem and the political elite that promote gas drilling. Residents say that politicians are masking or denying the negative impacts of the gas drilling industry, while elevating the positives, silencing those that have been marginalized by the impacts of the natural gas industry. "They (in reference to the commissioners) don't want people in the state to think that it is a problem, they want everybody to think that the gas business is wonderful" (Jill, Personal Communication, 2012). Few channels for democratic-decision making exists in relation to how drilling should be conducted and proceed, those in power effectively decide what is an issue and how the conversation will proceed. Free market ideologies predominate. In sum, leasing takes place between individual private landowners and a gas company. The public, it is presumed, should have no say in this process. Yet, as my research makes clear all residents of Bradford County are confronting issues associated with the natural gas boom.

At the state level new legislation is being proposed to strip away the power of local government and landowners. As communities experienced negative impacts of the drilling industry a push was made to enact new ordinances and laws prohibiting gas drilling in certain areas, specifically in residential zones or close to schools and hospitals, this major push to limit 
drilling came after the blowout in Bradford County. House Bill 1950 is a piece of legislation that was proposed out of the governor's office that would strip local municipalities or counties of the power to impose tough local restrictions of gas wells and pipelines. The legislation imposes an impact fee on gas drilling and provides a certain percentage of that fee to the county in which the drilling is taking place. In order to receive this money, the county or municipality cannot have any laws that restrict drilling activity. This legislation forces communities to choose between protecting certain areas and receiving much needed revenue. It also opens up large amounts of land to the possibility of drilling. This legislation was viewed as a major victory for the gas industry in further exerting their control over both the resource and the local communities. Using the legal power of the state, energy companies will be able to gain control and access to land for drilling and pipelines. Many local leaders expressed their concern over the legislation and the new resource grab that would ensue along with the loss of people's property rights and power over local governance (Tavernise, 2011). As of now the legislation has passed and impact fees are being collected, but the provision that requires municipalities and counties to allow drilling in all areas is being contested to the Pennsylvania Supreme Court.

Another piece of legislation that should be of concern to local landowners is House Bill 977, which deals with the issue of forced pooling. Forced pooling is "Similar to an eminent domain or condemnation proceeding, forced pooling permits landowners or operators to apply directly to the regulatory body with jurisdiction over oil and gas operations in the area to compel all mineral rights owners interested in a designated spacing unit to participate in its development" (Schlegel, 2011). The idea is to prevent a landowner from hindering development of a unit by refusing to lease their mineral rights to a gas company or operator. Currently the 
laws regarding forced pooling in Pennsylvania do not apply to the Marcellus Shale formation, however if this legislation is passed it would represent a major loss of control to local property owners over land use practices. The bill requires an operator to acquire 75 percent of the land in a proposed unit before applying for a pooling order. When the pooling order is applied for the other 25 percent of the landowners would be forced to lease their mineral rights to the gas company, regardless if they wanted to. The gas industry argues that this would allow the most efficient extraction of natural gas while protecting the surface environment from a proliferation of gas wells. Some landowners are extremely worried that this law would infringe upon their property rights, forcing them to be a part of something they never agreed to. "The great gas grab known as "forced pooling" -- allows the taking of mineral rights against the wishes of a property owner so that gas companies and opportunistic neighbors can harvest profits stored under your home" (Epstein, 2012).

Ross Pifer of the Agricultural Law and Reference Center at Penn State University's Dickinsion School of Law was quoted in The Time Tribune as saying.

If our policy is to extract the gas in the most efficient way possible, then we want to establish procedures that all of the gas can be extracted. But that can conflict with somebody's individual property interests in determining if they want to participate or determining the terms of their participation. That's the conflict that the General Assembly is going to have to deal with. How do you balance those two interests? (Legere, 2010) This legislation develops a procedure that takes the decision of participation out of the hands of the landowner and gives the decision making power to the state. This legislation has not yet passed, but it represents a major procedural injustice as power shifts from local landowners into the hands of politicians and industry. During my interviews local residents were unaware of this legislation; they were never asked for their opinions on the legislation and have been left out of 
the conversation. In Bradford county local officials have favored gas drilling highlighting the positive benefits of the industry while ignoring its negative impacts, holding local meetings to explain the potential benefits. The political process has effectively neglected the perspectives of local residents which in large part remain relatively absent and unaware of the debates taking place.

\section{Discussion: Losing Control}

I argue that the resource grab for natural gas represents an example of accumulation by dispossession. The natural gas resource grab has opened new markets and led to the privatization of resource rights that has enabled capitalist accumulation during the bust in the real estate bubble and financial crisis in 2008. The resource grab throughout Bradford County was financed by global capital, but has been facilitated by landmen, lawyers and the legal framework established by the state of Pennsylvania. Ultimately, the leases themselves are enforced by the state. Accumulation by dispossession in Bradford County is occurring through deep pocketed corporations, highly skilled lawyers, researchers, well-crafted legal documents, and the court system that makes this resource grab legal. In an article published by WVIA, one local resident said that "if all the [company] trucks were painted in military camouflage, you'd think they were being occupied by an unfriendly foreign power." (Kelly, 2010) This quote may not be far from the truth, with the majority of the land in the county being leased to gas companies, the region is in fact being occupied and taken over and there is not a lot residents can do to stop it. Taking control over the resource is just the first step in a much longer process that residents would soon begin to experience. Concerns about the corporate takeover of land and resources are not only a problem facing landowners. It has also had a major impact on the local community. 
I argue that the condition of possibility for the natural gas boom was the dispossession of resources from residents in Bradford County. Dispossession refers to the shift of resource control from the hands of local residents through market incentives and legal maneuvering and bringing those resources under the control of corporations, banks and financial markets. The initial dispossession that occurred in Bradford County is the key starting point to consider when examining current issues taking place in the region. The significance of this dispossession and the fact that large energy companies now control vast amounts of land in the county cannot be understated. This dispossession served as a way to bring new territory under capital control and reproduction through the exploitation of resources. While accumulation by dispossession literature on land grabbing focuses heavily on the land grab taking place in the global South ( Glassman, 2006, Gordon and Webber, 2007, Kaup, 2010, Spronk and Webber 2010) the Marcellus shale play is a clear example of how land grabbing takes place in the global North.

Through legal means large corporations with vast amounts of capital are able to take over and control large amounts mineral resources through leasing procedures that are designed to benefit the subsurface owner over that of the surface owner. The legal procedures in fact benefit those individuals or corporations with large amounts of capital and promote continued accumulation into the hands of these entities. The dispossession within the sphere of natural gas in the Marcellus shale was based upon the speculative science of how much gas could be retrieved from the shale and the potential price at which that gas could be sold. The investment was made based upon the future potential for production and profitability. In fact Chesapeake energy uses the leased land as an asset to obtain further capital investment into the company, beyond that the company also sells the future production of wells as a way to garner more capital 
for continued investment into mineral resources. While ownership of surface land remains intact, Bradford County is in fact now owned by a complex web of capitalist firms, investors and hedge funds from around the world.

While speculative economic discourses circulating in the media and political arena suggest that the natural gas boom in the county will bring money and jobs into the region, the long term viability and sustainability of that growth is uncertain. Appalachia provides many examples of towns and communities that have went through boom and bust cycles related to resource extraction. While this conversation in Appalachia has historically centered on coal, there is an echo of this past occurring in the development of natural gas today. The factors discussed above in relation to well productivity and the price of the commodity all influence the potential long term economic outcome local residents may realize. While natural gas extraction is packaged and sold by politicians and gas company representatives, through town halls and newspaper ads, as being a great economic engine for the region, cracks are already beginning to emerge in this argument. With the fall in gas prices the boom in Bradford County has already begun to decline, with drilling rigs moving to other regions holding more profitable gas deposits i.e. wet gas. There also existed a speculation that everyone would be able to benefit from the gas drilling occurring in the region, whether it was through leasing their gas rights, increased business, or better paying jobs working for the industry.

However, it is clear that a distributive injustice exists in Bradford County in the context of natural gas drilling in the Marcellus Shale. Some landowners received large amounts of money for their land, while others that had signed early were locked into poor prices for their land. The example of Jill mentioned earlier is a prime example of the distributive injustice that 
exists in the leasing process. Likewise certain members of the local population were able to capitalize on the boom, opening up new businesses, renting apartments or getting jobs with the industry. Yet a large amount of the population has not benefited from the gas boom and has in fact been unfairly burdened. This has taken the form of increased rents, traffic, crime, loss of social services, and a general degradation of the local community. The benefits of the gas boom have been unevenly distributed across the population, likewise the burdens have also been unevenly distributed; some people have become millionaires, while others have become homeless.

While there are clear environmental implications to natural gas drilling, the ways in which community members responded tends to focuses on potential environmental hazards that may occur rather than those that are occurring. Residents acknowledge that changes have occurred to the local environment, specifically in relation to water extraction for the fracking process and the clearing of land for well pads and pipelines. Yet the long term environmental impacts remain largely unknown. Is there a potential for chemicals to migrate and contaminate ground water or for the sand and water to lubricate fault lines causing more earthquakes, maybe or maybe not. No one actually knows what the environmental outcome from natural gas drilling in Bradford County will be. Some residents claim that their water has been contaminated and true a large list exists of people that have settled with gas companies over this contamination, yet an even larger group has not experienced any negative outcomes from the drilling process. This discourse is driven in large part by news outlets and environmental groups from around the country and in the local region and receives a lot of attention as a potential problem gas drilling may cause. Surprisingly my key informants took a rather pragmatic and optimistic approach to 
the discussion of environmental degradation, in a sense the environmental discourse did not resonate with what local residents viewed as their reality or they justified it based upon the potential economic benefits that may be realized.

The new flow of capital is transforming a farming region into an increasingly industrial landscape. These changes have worked to alter the perspective of the local community along with changing the lifestyles of its residents. While some have been made extremely wealthy, or "shaleionares," by the gas industry, others find themselves barely getting by or forced to move out of the county to regions with more reasonable rents (Jacobs, 2012). The industry has brought revenue to the region, yet the distribution of that revenue has served to exacerbate class conflicts and marginalize a larger proportion of the population. The distribution of revenue is not the only injustice occurring, as increased crime and rent rates are also affecting sectors of the population disproportionately. Specifically crimes rates have risen significantly in the borough of Towanda, while the major drilling beneficiaries live outside of the borough. The increased rents have burdened the most vulnerable segments of the population specifically the elderly and those with disabilities, or on fixed incomes. Residents do not always say that they have lost control, but their responses frequently intimate such feelings. In both the newspaper articles and my key informant interviews there is a sense of hopelessness. What is being done is out of their control. Their only choice is to live with it or move away. While the inability to go to the grocery store, or out to lunch, or get from place to place in a timely manner, might not be classified as a major loss of control, decisions over where to live or land use are.

Nevertheless, accumulation by dispossession (Harvey, 2003) has led to what I call social fracturing created by inequality, disruptions to everyday life and conflict between insiders and 
outsiders. What is often overlooked in the debates about natural gas drilling or resource extraction in general is the change in local community dynamics and interactions. The first thing out of peoples mouth's when asking about what has changed in the county since the gas boom was not about economic riches or environmental destruction, it was about traffic. Traffic, both symbolically and materially, resonates with people in Bradford County because it represents a clear and present change in the lives of local residents. This fracturing of society - often described in terms of time and space - is not hidden away on private property, deep underground within a well, or occurring in some far away corporate board room. These changes are taking place in the main street of Towanda, at the local bar, the grocery store or community service agencies, these changes are visible and part of the everyday interactions of local residents. This fracturing is part of people's everyday lives. It is what residents talk about, what upsets them and agitates them. As discussed in the previous section this discourse is not just confined to issues of traffic, but permeates other layers of the social life of local residents. The dispossession of natural gas has not only stripped away local control over the resource, it has also created a dispossession of community, as residents are forced to adapt to the new realities brought about by resource extraction and capital accumulation. The rising traffic, crime, or rent is a residual effect; the transfer of resource control forces residents into this situation. Social fracturing is a central reason for growing discontent in the county.

As social fracturing leads to discontent, it is clear that gas companies and the state are beginning to seek alternative ways to exert their control. Parallels can be drawn between what has happened historically in the coal fields of southern Appalachia and what is taking place contemporarily in Bradford County. A critical reason why the resource grab could occur in 
Bradford County is that no democratic procedure existed in deciding how land in the region should be used, because the majority of the land is privately held. Decisions were left entirely up to private landowners with limited information. The fact that the resource grab occurred in the shadows, like a thief in the night, meant that few procedures existed and public consent was not sought. As discussed earlier, many people were unaware the resource grab was taking place until much later in the process, when a major push was made by corporations to secure land and price wars began to break out. While some of my key informant's awareness was linked to their exposure in working with the industry through their jobs, other informants who I would characterize as the general non-landholding public was largely unaware. The tactics employed by these gas corporations limited the knowledge available to local residents, while giving an unfair advantage to the corporation. In essence the current structure means that in the early days of the gas boom local residents didn't stand a chance of negotiating a fair and good lease.

The growing concerns of county residents regarding social fracturing and to some degree the growing concerns about negative environmental impacts such as water contamination suggest that political conflicts may be on the horizon. However, while local communities may attempt to limit the activity of gas companies, the power of the state has been brought to bear to force open these territories to capital investment. This has come in the form of new state bills designed to eliminate barriers to resource acquisition by gas companies. The state government has become a way to override the authority of local governments and allow for the continued expansion of the gas industry. These goals are being accomplished through House Bill 1950 which limits the power of local governments to regulate the gas industry and prevent drilling. An attack is also being waged on the rights of private property owners to refuse to lease their mineral rights 
through House Bill 977 which will allow for forced pooling to take place. The argument behind these bills is to allow for the efficient development and extraction of natural gas, yet it is a major loss of control to both local communities and landowners. The state is in essence further facilitating the accumulation by dispossession process. There is a loss of control over the decision making process in Bradford County as the state begins to strip away local authority to open new territory up for capital exploitation. The state is acting in the best interests of capital by restricting local zoning, the effect is to open up more land for natural gas drilling.

The passing of Pennsylvania House Bill 1950, represents a major procedural injustice as the negotiations took place behind closed doors in the state capital and not publicly in the counties in which drilling occurs. As mentioned above, this bill gives wide sweeping powers to the state to sanction gas drilling, while stripping control over local land use practices from the community level. The bill also allows for the collection of an impact fee that will be distributed between the state, the county and the local municipalities. The provisions of the bill mandate that no community can receive money from the impact fee if any ordinance further limiting drilling beyond what the state has already passed is in place. While this provision is currently being debated in front of the Pennsylvania Supreme Court, it represents a major power and land grab by the state on behalf of the natural gas industry. While house bill 1950 works to strip power away at a community level, House Bill 977 aims to strip power away from local landowners. If passed this bill would represent a major loss of control to local landowners over their mineral rights. Once again the state is acting in the best interests of the gas drilling industry and not the broader public. In fact the state is stripping away one possible avenue landowners had to protect their land, simply not leasing. If this bill is passed, that may no longer be an 
option as corporations would be able to seize the land for production. This ability to seize land for corporate interests represents the power of the state being used to facilitate the continued accumulation of capital and is a perfect example of what Harvey (2003) terms accumulation by dispossession. In addition to this dispossession a procedural injustice exists throughout the entire resource grab, residents are incredibly vulnerable to economic and political manipulation and democratic procedures are either non-existent or being undermined by powerful forces.

\section{Conclusion}

The blowout in April 2011 created more than just an outpouring of toxic chemicals onto the land, it created an outpouring of debates and discourses concerning the impacts of natural gas drilling. The investigation into the blowout revealed that a faulty well head had failed under the immense pressure being put on it during the drilling process (PA DEP, 2012). What is happening today is in many ways the same thing that happened on that fateful day in April, as the social fabric begins to fracture under the immense pressure gas drilling has put on the local community; a social blowout has begun to occur. In moving the discussion forward, I argue that three things need to be addressed as a way to counter the negative impacts the loss of resource control has upon a community and individuals.

First- knowledge about the resource and navigation of the leasing labyrinth must be increased. The thief in the night tactics used by corporations to secure land rights left unsuspecting landowners vulnerable to exploitation. Land owners should be made aware of the potential value their resource may hold and the rights they have in negotiating a lease. This education process can help to limit the impacts of bullying, scare tactics, and lies used by landmen to coerce residents into leasing their mineral rights. Residents must also be vigil in 
examining their lease document, understanding the legal terminology, and the nuances written into the clauses of the lease. Residents as discussed earlier are often at an unfair disadvantage when negotiating a lease and this dynamic of power must be addressed to obtain fairer benefits for the landowner. One way of addressing this power imbalance is a framework could be developed to give residents the ability to negotiate and make decisions collectively. When residents are able to pull their resources together, they become much more formidable in the leasing and negotiation process. Someone that owns two acres of land is much less able to negotiate better lease terms, than say a group of residents that collectively own 35,000 acres of land. In one case a group of 900 landowners from Bradford County and the neighboring county, came together as a group and leased their 35,000 acres for \$192million (Hrin, 2009). In negotiating collectively, the benefits of leasing can be spread out between both large and small landholders, so that the best rate can be guaranteed for everyone, thus helping to address the distributive injustices found in the leasing process. When knowledge and collective bargaining are applied together, the leasing process can become extremely beneficial to the local landowners as Sandra gave me a local example.

People got together as a group as time went on, people got a little more educated got a little smarter so they would form groups here and they would pull all these large farms together and they would have meetings and they could go and have a town meeting with the gas companies and they were being offered between 5 and 6 thousand dollars an acre, some walked away with million dollar checks, just in leasing (Sandra, Personal Communication, 2012).

Second-the social fracturing and uneven distribution of benefits and burdens that occurs with resource extraction must be addressed. Even with fairer negotiations in the leasing process, some residents will remain excluded from the benefits of the gas boom. Residents that do not own land, those lacking the capital to invest in new businesses, or those unable to procure jobs 
with the industry will continue to be burdened by the impacts of gas drilling. This creates a complex problem, and no simple solution to addressing these issues exist. Residents unable to benefit from the leasing process deserve some form of compensation for the burdens put on them as a result of that leasing taking place. An impact fee is one place to start, but instead of the money collected going to the state and county government, the money should be distributed among the residents where drilling takes place. This would help to mitigate the negative impacts at an individual level. Yet, the impacts at the community level would still exist. This brings me to my third suggestion.

Third-a rebalancing of the political power structure needs to be addressed in which the political power of the state works for the interests of its citizens and not the interests of corporations or capital accumulation. This requires the state to address a more just distribution of control over the resource in which the benefits and burdens can be more evenly distributed. In addition a procedural framework needs to be developed to bring the interests and concerns of local residents into the discussion, as it stands now policy is being made in Harrisburg, while the drilling occurs a hundred miles away in Towanda. This geographic disconnect needs to be addressed as a way of establishing more fair and just policies.

While it can be argued that Bradford County is experiencing the typical growing pains of transitioning from an agrarian based economy to one of resource extraction, this approach to the analysis represents a new way to study the complex relationships resource control has upon a region. To avoid the negative impacts of resource extraction the discussion must be changed from looking only at the impacts of extraction (economic, environmental, social and political) and focused instead upon the root issue, control over the resource. As the nation moves forward 
with the development of domestically produced energy, the conflicts associated with resource extraction will no longer occur on distant desert landscapes or offshore platforms, far removed from the public's eye. Instead it will be occurring in people's back yards, on farms, state and community parks, near schools and hospitals. The changing geographic distribution of energy production will be a rude awakening to many people that never thought they would see drilling rigs in their neighborhood or local community.

Bradford County is the epicenter of the natural gas boom in the Marcellus Shale and should be studied and understood as other counties throughout the region and country grapple with similar issues. Being from Pennsylvania I know the stories of people that have lived through the successive waves of resource exploitation, how companies would come in and strip the forests for timber, dig into the earth for coal and drill for oil. In each case the resources of the state were plundered for the benefit of a few, while local populations were forced to suffer through environmental devastation, toxic pollution and contamination. My grandfather still remembers when the mountains used to be nothing but dirt, the trees completely stripped away. While the trees have grown back, till this day many streams in Pennsylvania remain dead to aquatic life, as acid from coal mines continues to seep into them. Natural gas could represent a bright future for Pennsylvania and its residents, but only if the benefits can be realized for everyone and not just a select few. Life is a gamble, but 40years from now I don't want to be telling my grandchildren about how large corporations once again plundered the state and left the local population with nothing but polluted land and streams. The people of Appalachia have a history of fighting back against exploitation and we are only just beginning to see that fighting spirit emerge. 


\section{Works Cited}

Achenbach, Joel. "Traditional Energy's Modern Boom." Washingtonpost.com. The Washington Post, 15 Aug. 2008. Web. 11 May 2012.

Allen, Bill. "Save Our Cumberland Mountains: Growth and Change Within a Grassroots Organization." Fighting Back in Appalachia: Traditions of Resistance and Change. Philadelphia: Temple UP, 1993. 85-100. Print.

Applebome, Peter. "Gas Drillers in Race for Hearts and Land" The New York Times 29 June 2008. Web. 15 June 2012.

Ardent, Hannah. Imperialism. New York, NY: Harcourt Brace and Company, 1964. Print

Alingod, Kris. "Pennsylvania Lawmakers Reach Compromise on Natural Gas Drilling Bill."GantDaily RSS. AHN News, 6 Feb. 2012. Web. 20 Jan. 2013

Ashman, Sam, Alex Callinicos. "Capital Accumulation and the State System: Assessing David Harvey's The New Imperialism”. Historical Materialism 14.4 (2006): 107-131. Print.

Baca, Marie C. "Donate." Pro Publica. Top Stories RSS, 18 May 2011. Web. 27 Mar. 2013.

Bingman, Mary Beth. "Stopping the Bulldozers: What Difference Did It Make?" Fighting Back in Appalachia: Traditions of Resistance and Change. Philadelphia: Temple UP, 1993. 17-30. Print.

Bowen, William M., and Michael V. Wells. "The Politics and Reality of Environmental Justice: A History and Considerations for Public Administrators and Policy Makers." Public Administration Review 62.6 (2002): 688-98. Print.

Brubaker, Harold. "Betting on a Bonanza; Energy Companies Leasing Land in PA. for Natural Gas." The Philadelphia Inquirer [Philadelphia] 6 July 2008, CITY-D ed., National sec.: A01. LexisNexis Academic. Web. 5 July 2012.

Bryner, Gary. "Assessing Claims of Environmental Justice." Island Press, Washington, DC. 2002. 31-55. Print.

Bullard, Robert D. Dumping in Dixie: Race, Class, and Environmental Quality. Boulder, Colo: Westview, 2000. Print.

Cable, Sherry. "From Fussin' to Organizing: Individucal and Collective Resistance at Yellow Creek." Fighting Back in Appalachia: Traditions of Resistance and Change. Philadelphia: Temple UP, 1993. 69-84. Print.

Clayton, Mark. "Controversial Path to Possible Glut of Natural Gas." The Christian Science Monitor. The Christian Science Monitor, 17 Sept. 2008. Web. 11 May 2012.

"Chesapeake Energy - America's Champion of Natural Gas." Chesapeake Energy - America's Champion of Natural Gas. Chesapeake Energy, 2013. Web. 19 Apr. 2013.Detrow, Scott. "BoomTown: How Drilling Has Changed Towanda, PA." Pennsylvania RSS. NPR, 10 Dec. 2012. Web. 27 Jan. 2013.

Detrow, Scott. "Five Years Into Fracking Boom, One Pa. Town At A Turning Point." NPR. NPR, 14 Jan. 2013. Web. 27 Feb. 2013.

Detrow, Scott. "Read the House GOP Impact Fee Bill: HB 1950." State Impact. National Public Radio, 2 Nov. 2011. Web. 15 Dec. 2012.

"Effects Of Fracking Laid Out: Pa. Farmers Speak During SP Meeting." Southern Pines Pilot. 13 Nov. 2011. Web. 27 Nov. 2011. <http://www.thepilot.com/news/2011/nov/13/effectsfracking-laid-out-pa-farmers-speak-during-/>. 
"EPA." Hydraulic Fracturing. United States Environmental Protection Agency, June 2010. Web. 23 Apr. 2013.

Fairhead, James, Melissa Leach, and Ian Scoones. "Green Grabbing: A New Appropriation of Nature?" Journal of Peasant Studies 39.2 (2013): 237-61. Print.

Fisher, Stephen L. (ed.) Fighting Back in Appalachia: Traditions of Resistance and Change. Philadelphia: Temple UP, 1993. Print.

Fitting, Elizabeth M. The Struggle for Maize: Campesinos, Workers, and Transgenic Corn in the Mexican Countryside. Durham [N.C.: Duke UP, 2011. Print.

Gaventa, John. Power and Powerlessness: Quiescence and Rebellion in an Appalachian Valley. Chicago: University of Illinois, 1982. Print.

Getches, David H., and David N. Pellow. "Beyond "Traditional" Environmental Justice." 3-30. Print.

Gill, Brad. "Homegrown Energy: The Facts about Natural Gas Exploration of the Marcellus Shale." Marcellus Facts. Independent Oil and Gas Association of New York, n.d. Web. 10 Feb. 2013.Goodell, Jeff. "The Big Fracking Bubble:The Scam Behind the Gas Boom." Rolling Stone. N.p., 15 Mar. 2012. Web. 4 May 2012.

Ginger. Personal Interview. November 192012

Glassman, Jim. "Primitive Accumulation, Accumulation by Dispossession, Accumulation by 'extraeconomic' Means." Progress in Human Geography 30.5 (2006): 608-25. Print.

Glen, John M. "Like a Flower Slowly Blooming: Highlander and the Nurturing of an Appalachian Movement." Fighting Back in Appalachia: Traditions of Resistance and Change. Philadelphia: Temple UP, 1993. 31-56. Print.

Hall, Kevin F. "Does Shale Oil Boom Mean U.S. Energy Independence Near?" McClatchy Washington Bureau. N.p., 21 Dec. 2011. Web. 18 July 2012.

Harvey, David. The New Imperialism. Oxford: Oxford UP, 2003. Print.

Hay, Ian. Qualitative Research Methods in Human Geography. Oxofrd, New York: Oxford University Press, 2010. Print.

Hicks, Brian. "Natural Gas Boomtowns Expect More Towandas and Steubenvilles." Wealth Daily. N.p., 20 Feb. 2012. Web. 18 June 2012.

Himley, Matthew. "Regularizing Extraction in Andean Peru: Mining and Social Mobilization in an Age of Corporate Social Responsibility." Antipode 45.2 (2013): 394-416. Print

Hird, J. A. "Ecopopulism: Toxic Waste and the Movement for Environmental Justice." Journal of Health Politics, Policy and Law 20.2 (1995): 509-13. Print.

Holifield, Ryan, Michael Porter, and Gordon Walker. "Antipode." Antipode 41.4 (2009): 591612. Print.

Hrin, Eric. "Concerns raised over impact of gas drilling in Bradford County" The Daily Review [Towanda] 7 Oct. 2008:n. LexisNexis Academic. Web, 13 June 2012.

Hrin, Eric. "Gas Leasing Becomes Hot Topic." The Daily Review [Towanda] 5 Apr. 2008: n. . LexisNexis Academic. Web. 13 June 2012.

Hrin, Eric. "Gas-lease Agreement Is 'very Good Deal'" TheDailyReview.com. The Daily Review, 14 Sept. 2009. Web. 11 May 2013.

Hrin, Eric. "McLinko Discusses View on Impact Fee." TheDailyReview.com. The Daily Review, 2008. Web. 11 June 2012.

Jill. Personal Interview. 21 November 2012.

Joyce. Personal Interview. 20 November 2012

Kelly, Bill. "Boom Town Towanda." Community Video. WVIA, 9 Dec. 2010. Web. 09 June 2012. 
Legere, Laura. ""Forced Pooling" Legislation for Gas Industry Planned in Pennsylvania." Times Tribune.com. The Times Tribune, 11 July 2010. Web. 27 Jan. 2011.

Legere, Laura. "Study Find Bromide in Water after Drilling However, No Fracking Impacts Were Found." The Daily Review [Towanda] 26 Oct. 2011. Thedailyreview.com. 26 Oct. 2011. Web. 15 Nov. 2011.

Lisa. Personal Interview. 20 November 2012.

Lowenstein, James. "Asking for Safe Water." TheDailyReview.com. The Daily Review, 27 Mar. 2009. Web. 12 June 2012.

Lowenstein, James. "Bradford County 911 Center Getting Busier with Population, Traffic Increase." TheDailyReview.com. The Daily Review, 16 Apr. 2010. Web. 12 July 2012.

Lowenstein, James. "Bradford County Commissioners Reduce Seats in Courthouse's Rotunda for Gas Workers." TheDailyReview.com. The Daily Review, 9 Apr. 2010. Web. 11 May 2013.

Lowenstein, James. "Bradford County DA Seeks to Document Impact of Gas Industry on Crime." TheDailyReview.com. The Daily Review, 11 Dec. 2009. Web. 12 June 2012.

Lowenstein, James. "Concerns raised over impact of gas drilling in Bradford County" The Daily Review, 7 Oct 2008. Web 15 June. 2012.

Lowenstein, James. "Gas drilling committee formed by commissioners" The Daily Review [Towanda] 11 Jul. 2008. LexisNexis Academic, Web, 13 June 2012.

Lowenstein, James. "Gas Company Official Expects Gas to Be a Boon for County."TheDailyReview.com. The Daily Review, 17 Apr. 2009. Web. 12 June 2012.

Lowenstein, James. "Residents: Dozens of Wells in Bradford County Have Been Contaminated." The Daily Review. N.p., 8 Apr. 2011. Web. 14 July 2012.

Lowenstein, James. "Local gas rush in Bradford County" The Daily Review, 4 Oct. 2008. Web. 12, Jun. 2012.

Lowenstein, James. "Resident Tells Bradford County Commissioners Not to Forget Gas Drilling Problems." The Daily Review. The Daily Review, 25 Feb. 2011. Web. 16 Apr. 2012.

Lowenstein, James. "Skyrocketing Rent in Bradford County: Influx of Gas Workers Creating Shortage of Affordable Housing." TheDailyReview.com. The Daily Review, 22 Jan. 2010. Web. 24 Oct. 2011.

Luxemburg, R 1951: The accumulation of capital. New Haven, CT: Yale University Press.

Marshall, Peter "How Fracking affects a community in Pennsylvania" BBC.co.uk BBC News, 28 Nov. 2011. Web. 18 Jun. 2012.

Maykuth, Andrew. "Marcellus Shale Gas Development Fueling Bradford County Boom." Philly.com. The Inquirer, 27 Dec. 2010. Web. 20 Jan. 2012.

Maykuth, Andrew. "Marcellus Shale Dispute Bubbling up in Northeast Pennsylvania." The Philadelphia Inquirer 4 July 2010, City-C ed.: n. pag. LexisNexis Academic. Web. 12 June 2012.

"Marcellus Shale - Appalachian Basin Natural Gas Play." Marcellus Shale Gas: New Research Results Surprise Geologists! Geology.com, 23 July 2008. Web. 19 Apr. 2012.

Mellott, Kathy. "'It Will Get Messy': Bradford County Residents Say Drilling Brought Changes » Local News » The Tribune Democrat, Johnstown, PA." Tribunedomocrat.com. The Tribune-Democrat, 13 Dec. 2010. Web. 11 May 2012.

Millner, Felicity. "Access to Environmental Justice." Deakin Law Review 16.1 (2011): 189-207. Print. 
Mutz, Kathryn M., Gary C. Bryner, and Douglas S. Kenney.(ed.) Justice and Natural Resources: Concepts, Strategies, and Applications. Washington, DC: Island, 2002. Print.

Needles, Zack. "Must Crime Follow Pennsylvania's Gas Drilling Boom?" Post-Gazette.com. Pittsburgh Post Gazette, 15 Aug. 2011. Web. 16 Nov. 2011.

"PA Environment Daily: 6 Environmental Groups Decry Passage Of Marcellus Shale Bill." PA Environment Daily: 6 Environmental Groups Decry Passage Of Marcellus Shale Bill. PA Environment Digest, 8 Feb. 2012. Web. 20 Jan. 2013.

Patriot News Op-Ed. "Central PA." The Patriot-News. N.p., 14 Aug. 2011. Web. 27 Jan. 2012.

Philips, Susan. "Chesapeake to Pay \$1.6 Million for Contaminating Water Wells in Bradford County." Pennsylvania RSS. NPR, 21 June 2012. Web. 27 Mar. 2013.

Plumer, Brad. "Is Fracking a 'bridge' to a Clean-energy Future? Ernest Moniz Thinks So."Washington Post. The Washington Post, 4 Mar. 2013. Web. 23 Apr. 2013.

Pulido, Laura. Environmentalism and Economic Justice: Two Chicano Struggles in the Southwest. Tucson: University of Arizona, 1996. Print.

Pulido, Laura. "Rethinking Envrionmental Racism: White Privilege and Urban Development in Southern California" Annals of the association of American Geographers. 90.1 (2000) 12-40. Print.

Reuther, Mike. "Gas Industry Ripple Effect Pricing Some out of Homes." SunGazette.com. The Sun Gazette, 7 Feb. 2010. Web. 11 May 2012.

Rhodes, Edwardo Lao. Environmental Justice in America: a New Paradigm. Bloomington: Indiana UP, 2003. Print.

Romm, Jeff. "The Coincidental Order of Environmental Injustice." Print.

Rubinkam, Michael. "Pa. Accused of Rubber-Stamping Numerous Gas Permits." Associated Press 13 Apr. 2011. Print.

Sandra. Personal Interview. 19 November 2012.

"Senate Committee Hears Testimony On Housing Impacts Of Marcellus Shale Drilling." PA Environment Digest. PA Environment Digest, 25 Jan. 2010. Web. 23 Jan. 2012.

Schlegel, Jeffrey A. "Forced Pooling in the Marcellus Shale: Where Is Pennsylvania Headed?" Jones Day Publications. N.p., Jan. 2011. Web. 23 Feb. 2013.

Schroder, Richard A., "Tanzanite as conflict gem: Certifying a secure commodity chain in Tanzania" Geoforum 41 (2010) 56-65. Print.

Schwartzel, Erich. "Fouled Waters: Woodlands Residents Search for Ways to Survive without Clean Water." Post-Gazette.com. Pittsburgh Post Gazette, 19 Aug. 2012. Web. 27 Mar. 2013.

Schlosser, Kolson. "Regimes of Ethical Value? Landscape, Race and Representation in the Canadian Diamond Industry" Antipode 45.1 (2013): 161-179. Print.

Spencer, Starr. "Chesapeake Energy details 7.5-20 Tcf Gas Find; New US plays could reverse LNG import needs: CEO” Oilgram News 86.60 26 Mar. 2008. Print

Spencer, Starr. "US gas shale sites drawing crowd of players; Marcellus, Hanesville, and \$11/Mcf gas, prove irresistible. Oilgram News 86.103 27 May. 2008. Print.

Srponk, Susa, Jeffrey R. Webber. "Struggles against Accumulation by Dispossession in Bolivia: The Political Economy of Natrual Resource Contention" Latin American Perspectives 34 (2007) 31-47. Print.

Stouffer, Rick. "Pa. Atop Natural Gas Mother Lode" The Pittsburgh Tribune, 4 April 2008. Web. 18 Nov. 2011. 
Strauss, Kendra. "Accumulation and Dispossession: Lifting the Veil on the Subprime Mortgage Crisis" Antipode 41.1 (2009): 10-14. Print.

Swift, Robert. "Bradford County Woman Addresses Gas Rally." The Times-Tribune. The Times Tribune, 8 June 2011. Web. 23 Apr. 2012.

Todd Gordon \& Jeffery R Webber. "Imperialism and Resistance: Canadian Mining Companies in Latin America" Third World Quarterly, 29.1 (2008): 63-87. Print

Towers, George. "Applying the Political Geography of Scale: Grassroots Strategies and Environmental Justice." The Professional Geographer 52.1 (2000): 23-36. Print.

Warner, Dave. "Neighbors of U.S. Gas Well Blowout Fear the Worst." Reuters. Thomson Reuters, 21 Apr. 2011. Web. 11 May 2013.

Watts, Michael. "Empire of Oil: Capitalist Dispossession and the Scramble for Africa" Monthly Review: An Independent Socialist Magazine. September 2006. Print.

Walker, Gordon. "Beyond Distribution and Proximity: Exploring the Multiple Spatialities of Environmental Justice." Antipode 41.4 (2009): 614-36. Print.

"US Shale Plays:." Natural Gas Week (19 Oct. 2009): n. pag. LexisNexis Academic. Web. 12 June 2012. 


\section{a. Maps}

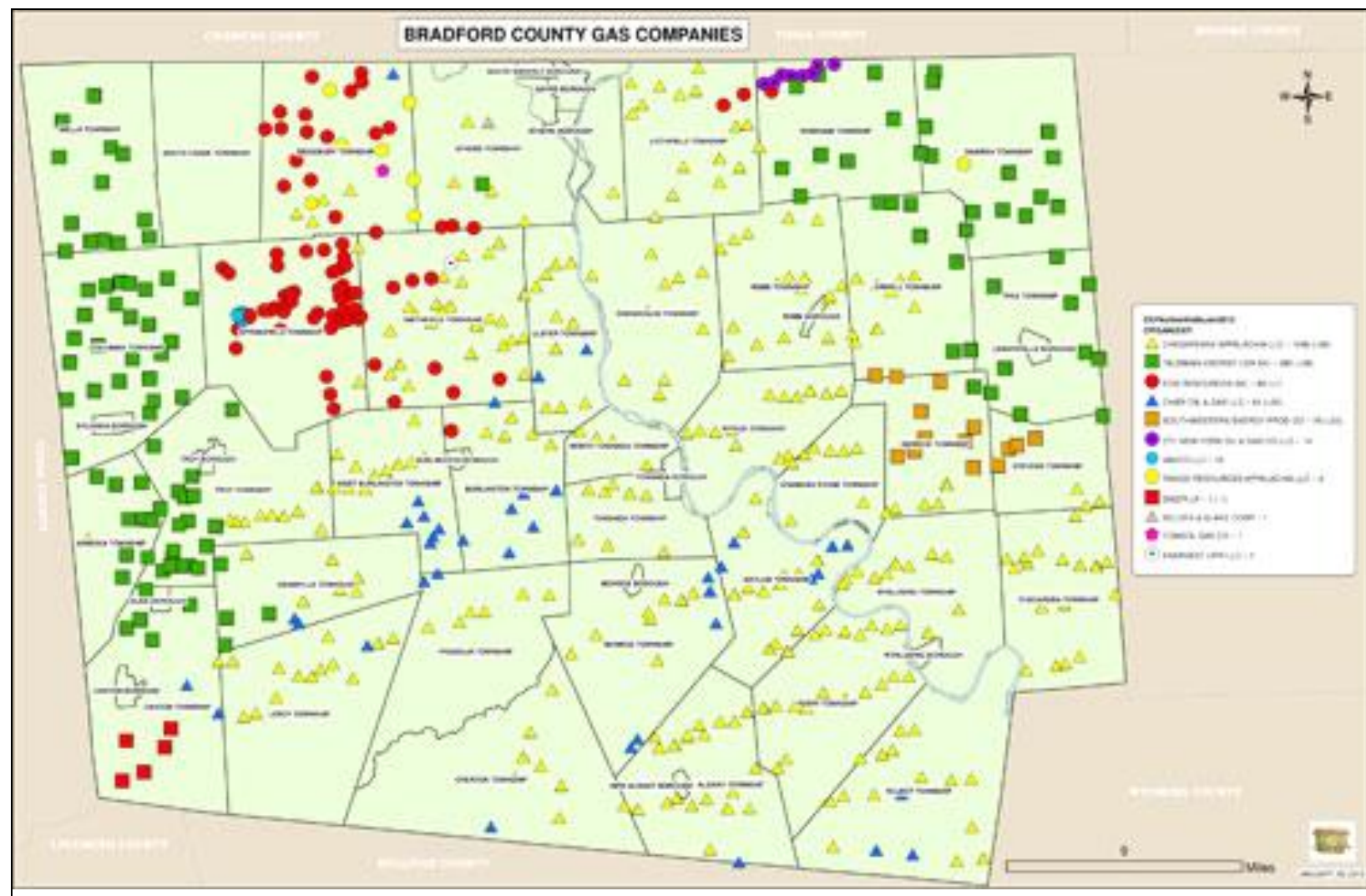

Figure 1:Permitted or active gas wells in the County

(Map created by the Bradford County Office of Planning and Grants) 


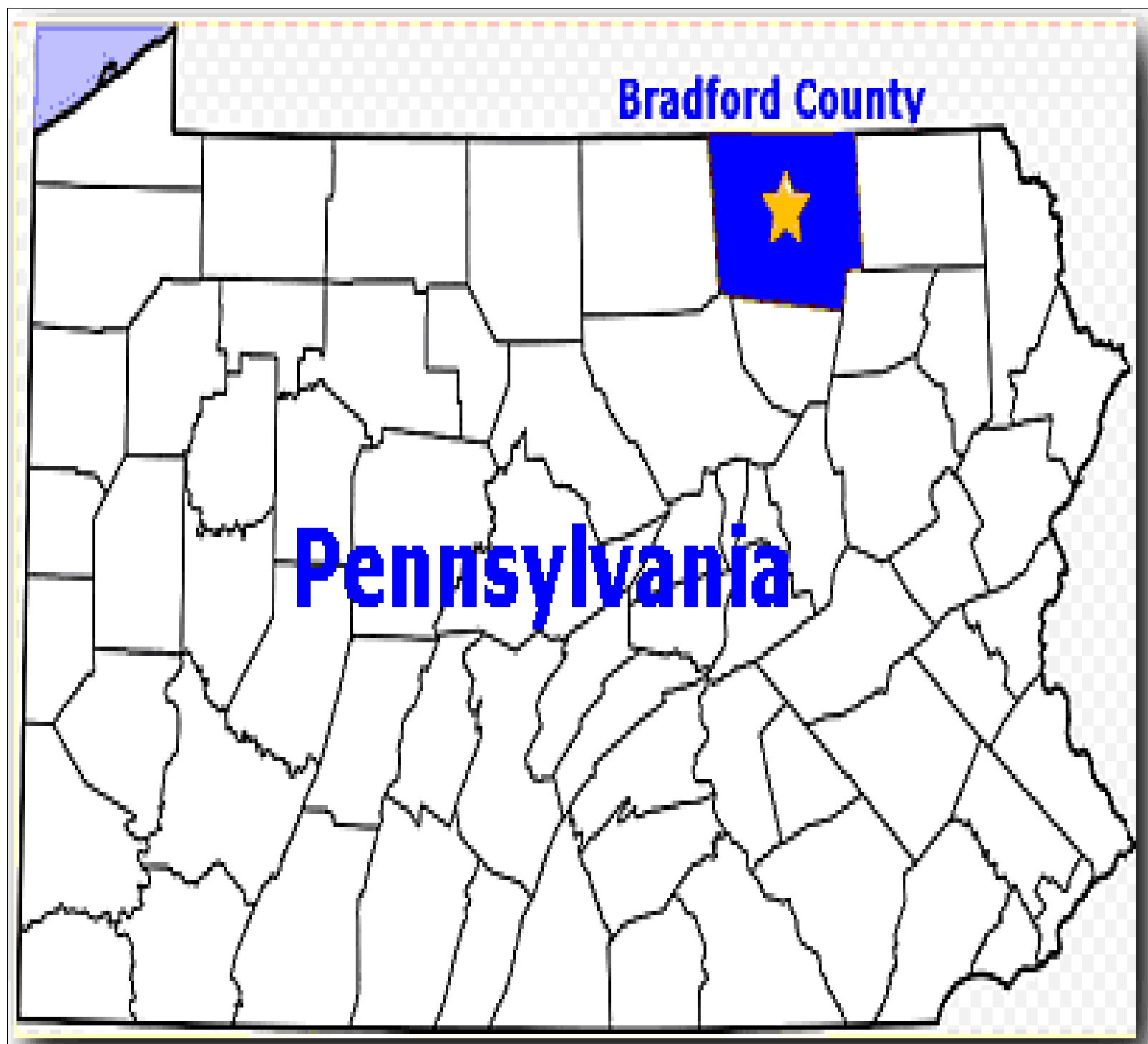

Figure 2: Location of Bradford County in PA

(Map curtsey of http://bradcolibrarysystem.org/) 


\section{b. Table}

\begin{tabular}{|c|c|c|c|c|}
\hline \multicolumn{4}{|c|}{ Newspaper Article Breakdown } & \\
\hline Year & Environmental & Social & Economic & \\
\hline 2003 & 1 & & 1 & 1 \\
\hline 2004 & 1 & & 1 & 1 \\
\hline 2005 & 0 & 0 & 0 & 0 \\
\hline 2006 & 2 & 1 & 2 & 2 \\
\hline 2007 & 0 & 0 & 0 & 0 \\
\hline 2008 & 8 & 8 & 17 & \\
\hline 2009 & 3 & 5 & 9 & 9 \\
\hline 2010 & 7 & 11 & 13 & \\
\hline 2011 Blowout & 18 & 14 & 9 & 9 \\
\hline 2012- November & 9 & 19 & 17 & \\
\hline Total & 49 & 58 & 69 & \\
\hline
\end{tabular}




\section{c. Figures}

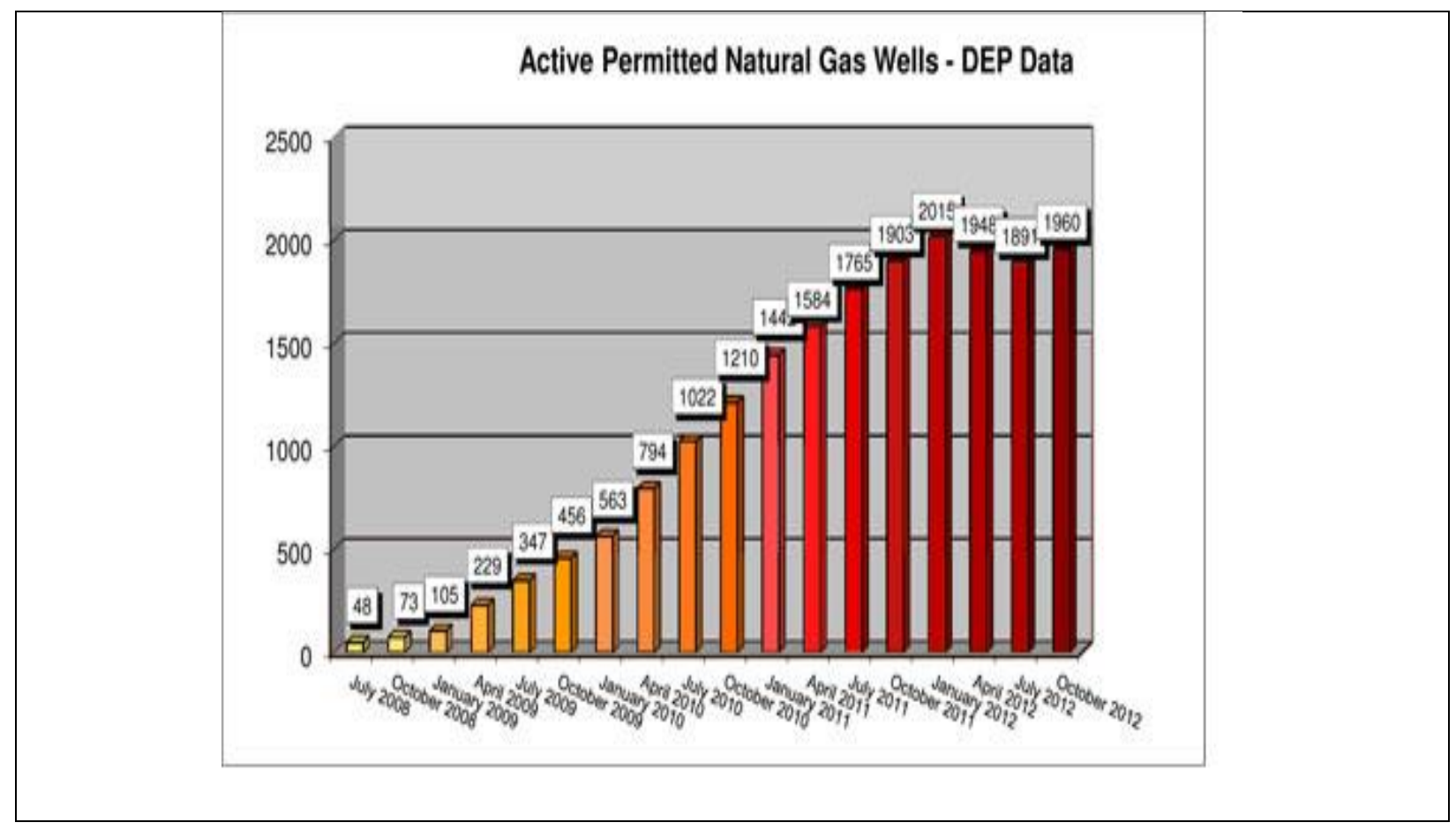




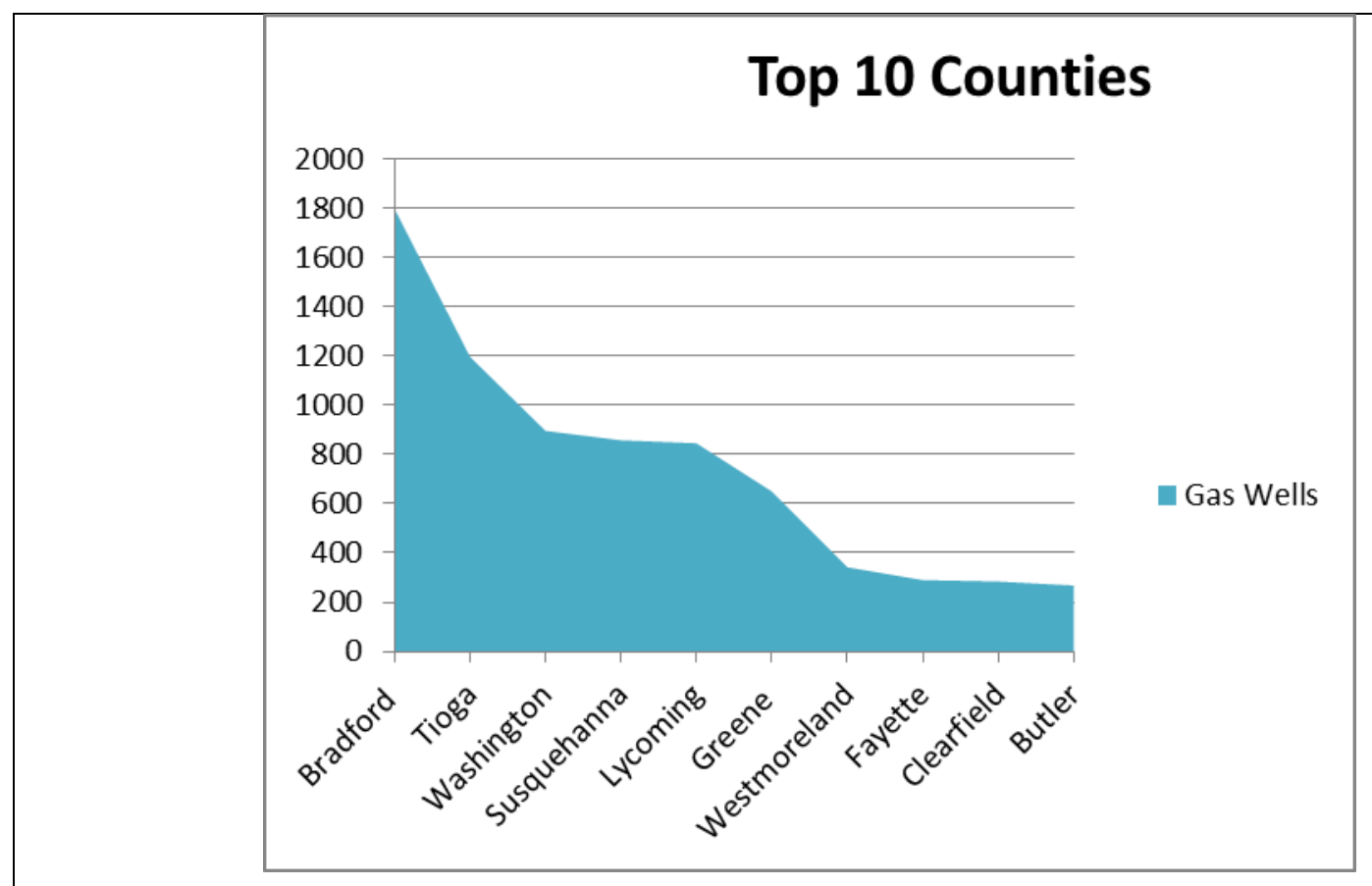

Figure 3: Active permitted natural gas wells and a comparison of wells drilled in Bradford County to other counties in the state of Pennsylvania. 


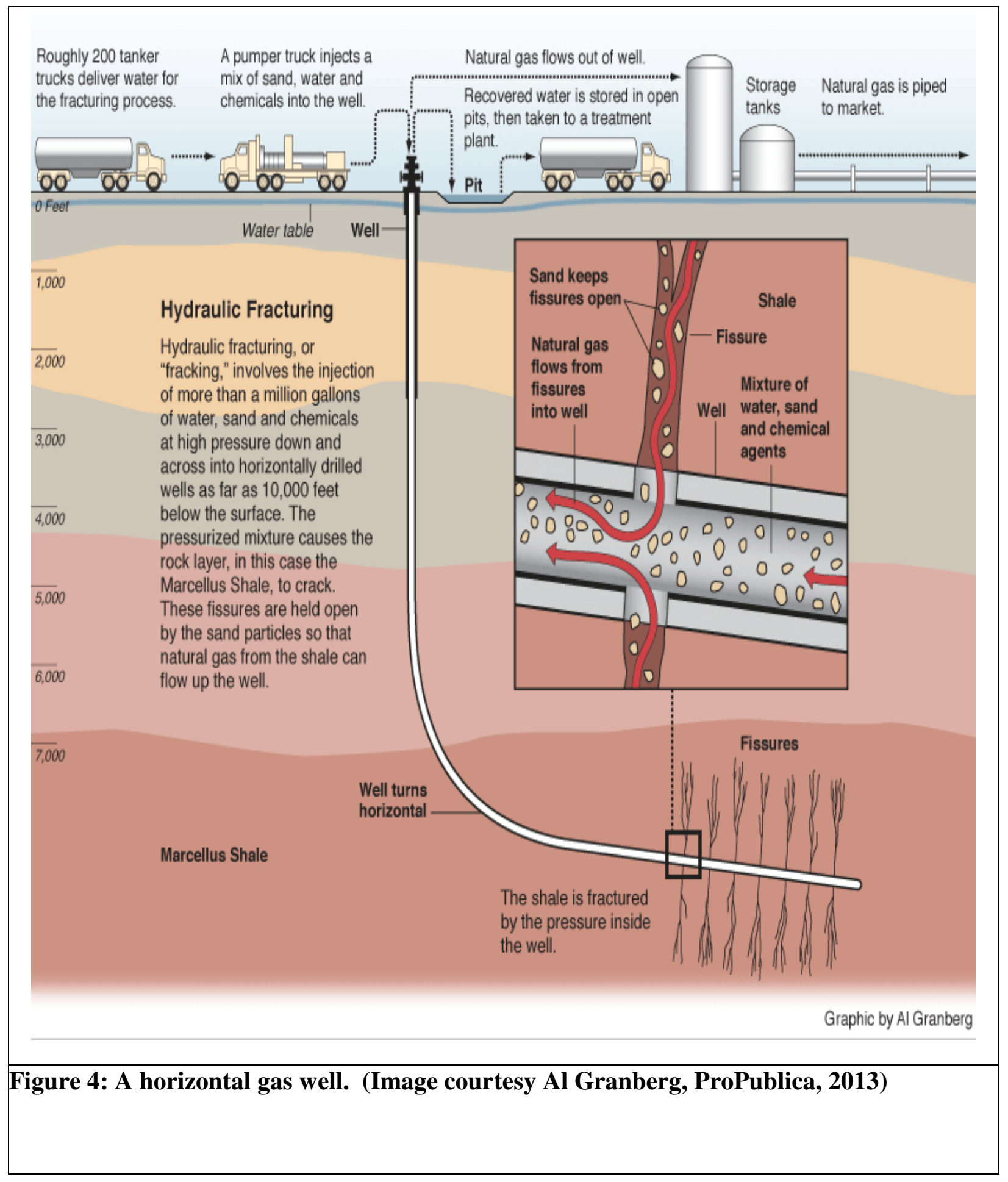




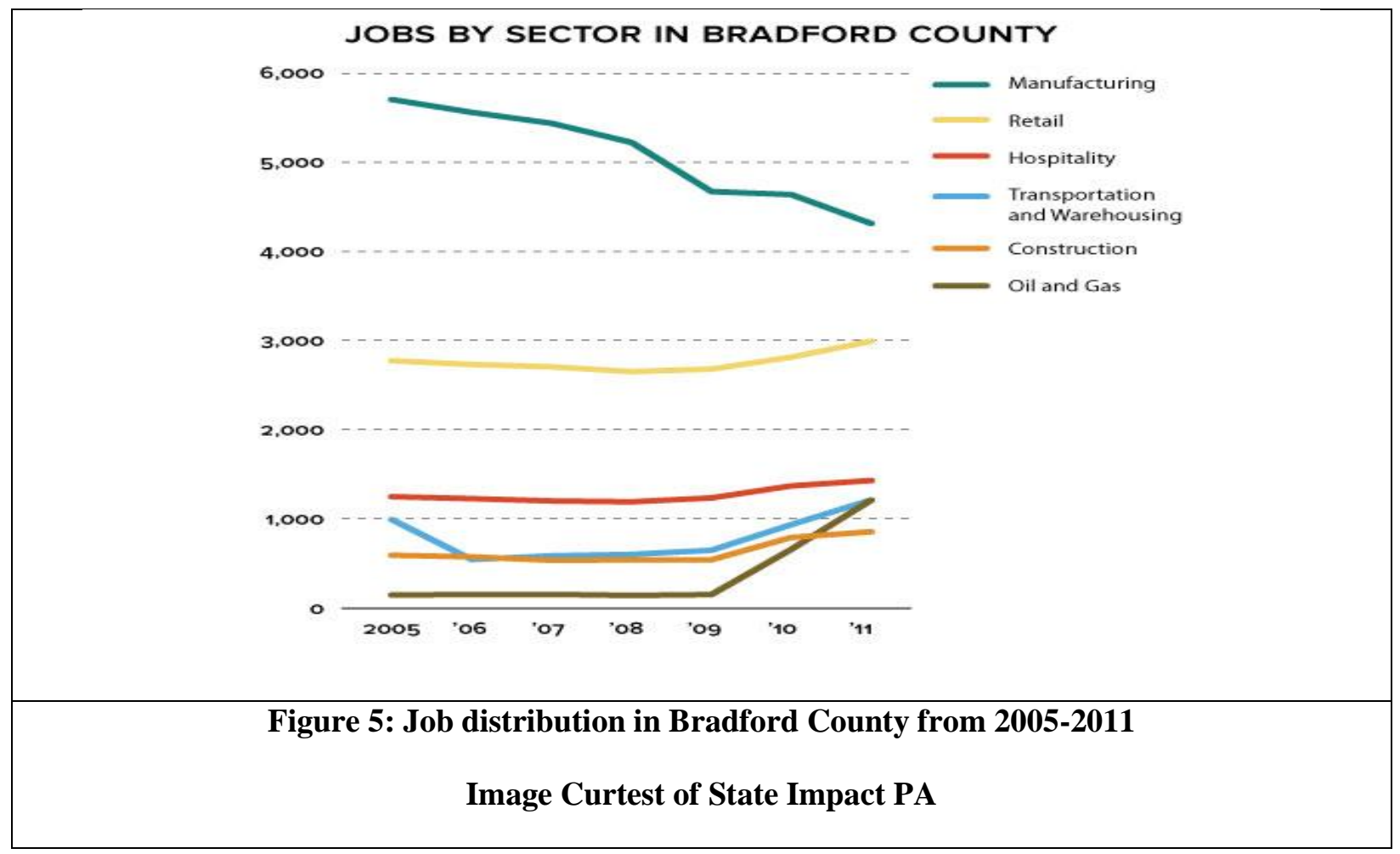

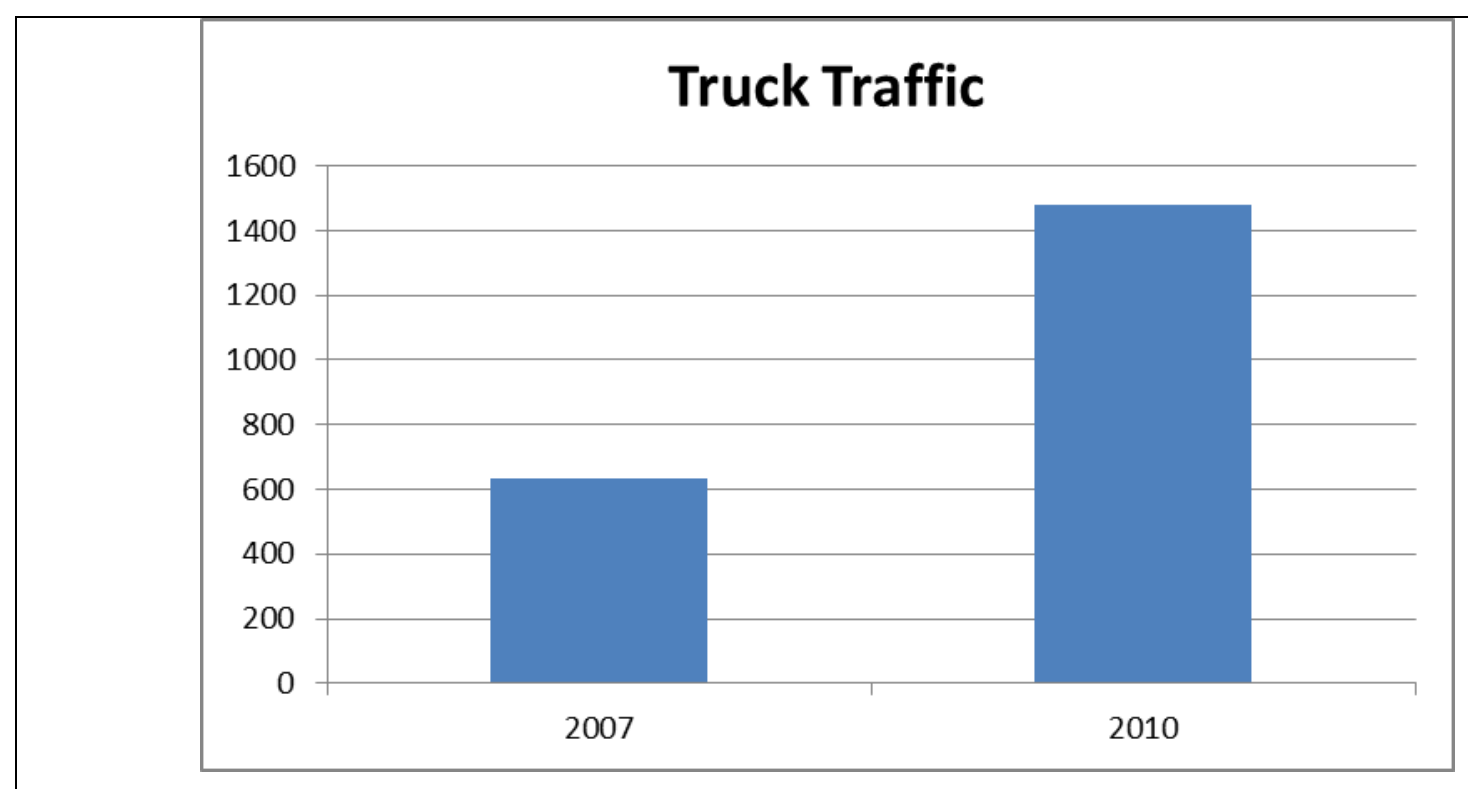

Figure 6: Increase of Truck Traffic from 2007 to 2010 


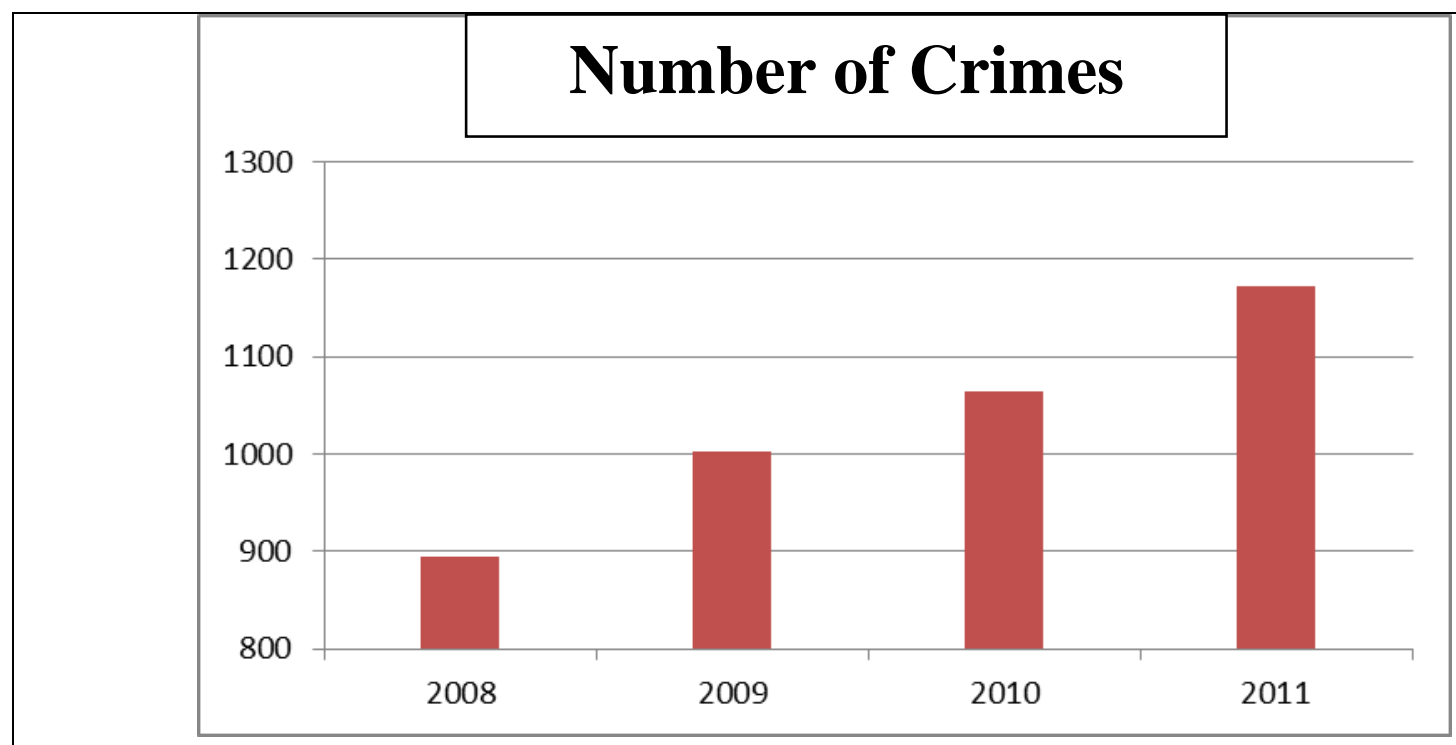

Figure 7: Number of Crimes from 2008-2011

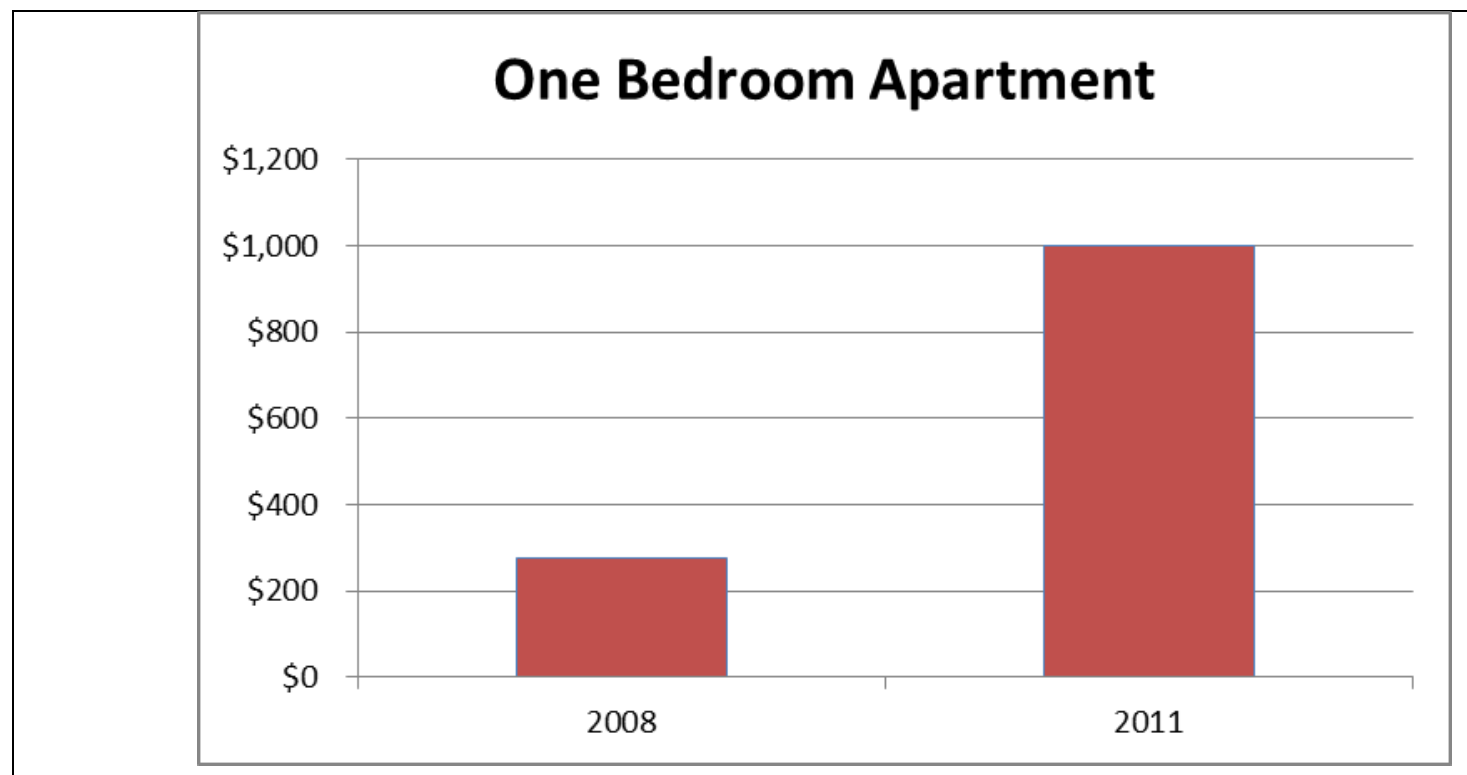

Figure 8: Increase in rent for a one bedroom apartment from 2008-2011 
d. Appendix

A 


\section{DECLARATION AND NOTICE OF POOLED UNIT BARNES UNIT}

This Declaration and Notice of Pooled Unit is executed to be effective as of September 10, 2010. by the tndersigned parties, who collectively own the leasehold estates created under those centain oil and gas leases and ary renewals, extensions, ratifications and amendments thereof which are more particularly described on Exhibit "A" attached hereto and incorporated herein by reference for all purposes (the "Leases"), or who collectively own an interest in the ofl and gas estate in the lands described in the Leases, and who join in the execttion hereof to evidence their consent to the pooling, unitization and combination of the leases and ofl and gas estates herein described.

RECITALS

WHEREAS, each of the Leases authorizes the lessee thereunder to pool, unitize or combine all or a portion of the lands covered thereby with other land and lesses, to form a pooled unit for the exploration, development and production of oil, gas and associated and constituent hydrocarbons from the lands covered by the Leases; and

WHEREAS, the pooling, unitization and combination of the Leases and oil and gas estates to the extent necessary to form the hereinafter described pooled unit are necessary and advisable in the judgment of the undersigned to efficiently and effectively develop the oil and gas rights within such unit. WHEREAS, Chesapeake Appalachia, L.L.C. is the Operator of the gas well(s) in the pooled unit and executes this document on behalf of itself and as agent for all interest owners in the leases to the extent that they do not separately join in the execution hereof.

NOW. THEREFORE, in order to establish and provide propet notice of the ereation of the hereinafter described pool or unit, the undersigned hereby declare as follows:

1. Declaration of Unit: In accordance with the provizions of the Leases, the undersigned do hereby declare, pool, unitize and combine the Leases, including all renewats, extensions, ratifications and amendments thereof, and the lands covered thereby and the oil and gas estates therein, to the extent necessary to form and create a pooled unit as described below. Production from the unit shall be allocated among all of the Leases and tracts within the unit in the proportion that the number of surface acres of each lease and tract Included within the unit bears to the total number of surface acres in the unit, as described in Exinibit "A".

2. Unit Name. The pooled unit created hereby shall be known as the "Barnas Unit" ("the Unit").

3. Description of Unit: The Unit shall consist of 663.245652 acres, more or less, being all or a portion of the Leases listed on Exhibit "A" INSOFAR AND ONLY INSOFAR as the Leases fall within the boundary more particularly descrlbad and depicted on Exhibit " $B$ ". which is attached hereto and incorporated herein by reference for all purposes. This Declaration and Notice of Pooled Unit covers al production from the lands described on Exhibit " $\mathrm{A}$ " and Exhibit " $\mathrm{B}$ " which is produced from any well dritled within the unit. To the extent of any inconsistency between the information contained on Exhibit " $A$ " and that depicted on Exhibit " $B$ ", Exhibit " $A$ " shall supersede and control 
4. Effect of Pooled Unit. The effect of this Declaration and Notice of Pooled Unit shal be that operations and/or production (or the equivalent as in the case of shut-in payments) anywhere within the Unit stall be deemed to be operations and/or production on each separate tract sufficient to extend and maintain each included lease in the Unit.

5. Right to Amend, The undersigned hereby expressly reserve the right, from time to time, to amend this Declaration and Notice of Pooled Unit, and the respective terms and provisions hereof, and to change the size and area of, and Interests covereo by the Unit, including without limitation, the power (i) to change, reduce, enlarge or extend the size or conflguration of the Unit; (II) to include in the Unit additional lands and oll and gas leases, or interests in the lands described therein, covering interests in the Unit, which are secured or obtatned subsequent to the date hereof, or prior to the date heroof and not included and described herein; (iit) to include in the Unit full or undivided interests in the Unit which are not otherwise included herein by the respective owner of such full or undivided interests; and (iv) to change the allocation of oll and gas production attributable to the various lands leases and owners thereof to conform with (i) - (iii) above.

6. Dissolution of Unit: The Unit formed hereby may be dissolved by Chesapeake Appalachia, L.L.C., acting as the Operator of the Unit, with the consent of the undersigned, at any time by filing an appropriate instrument of record in Bradford County, Pennsylvania, after any failure to establish unit production or after cessation of operations upon the Unit

7. Binding upon Assigns and Successors: This instrument shall bind, inure to the benefit of, and be exercised by heirs, assigns, and successors in interest of all parties.

8. Counterparts. This document may be executed in one or more counterparts, asch of which will be deemed to be an original for all purposes and all of which, when taken together, will be deemed to consfitute one and the same document as if all signatures were included therein. The failure of one or more of the signatory parties isted below to execute this instrument or a counterpart thereof shall not in any manner affect the validity of same as to the parties who do execute this instrument.

9. Effective Date: This Unit shall remain in force from the effective date listed hereinabove and for as long as oil and ges are being produced from the Unit, of so long as the Leases are maintained in force and effect by payment or tender of shut-in royaltes, or by other means, in accordance with the terms and provislong of the Leases.

EXECUTED by the undersigned parties on the respective dates of acknowledgment hereof, to be effective for all pupposes as of the date first above written.

$-2-$ 


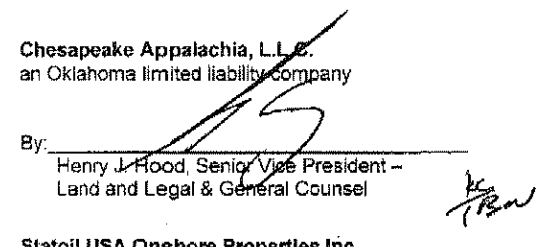

Statoil USA Onshore Properties Inc.

By

M.K. Williams, Land Manager - Onshore Gas

Talisman Energy USA, Inc.

By

Darin A. Zanovich, Attomey-in-Fact

EOG Resources, Inc..

By:

Williams Exploration \& Production

By: 
CORPORATE ACKNOWLEDGMENT

STATE OF OKLAHOMA ) SS:
COUNTY OF OKLAHOMA)

On this, the 4 day of May, 2011 , before me Keare th lsted the undersigned officer, personally appeared Henry J. Hood, who scknowledged himself to be the Senior Vice President - Land and Legal \& General Counsel of Chesapeake Appalachia. L. L.C., an Oklahoma limited liability company, and that he foregoing instrument for the purpose therein contained by signing the name of the limited liability company by himeself as Seriior Vice Prosident - Land and Legal \& General Counsel.

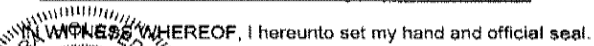

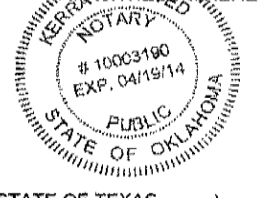

My Commission Expiras: $\quad 4 / 19 / 14$

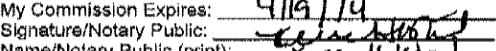

Name/Notary Public (print):

CORPORATE ACKNOWLEDGMENT

STATE OF TEXXS

COUNTY OF HARRIS

On this, the day of

tay of _... 20 , before me

the undersigned officer personally appeared M.K. Williams, who acknowledged himself to be the Land Manager - Onshore Gas of Statch USA Onshore Propertes inc. a corporaton, and that he as such Land Manager - Onshore Gas, being autherized to do $5 \mathrm{O}$, oxecuted foregoing instrument for the purpose therein contained by signing the name of the corporation by himself as Land Manager - Onshore Gas.

IN WITNESS WIHEREOF, I hereunto sęt my hand and official seal

My Commission Explies:
Signature/Notary Public:

Nammet Notary Public (print)

CORPORATE ACKNOWLEOGMENT

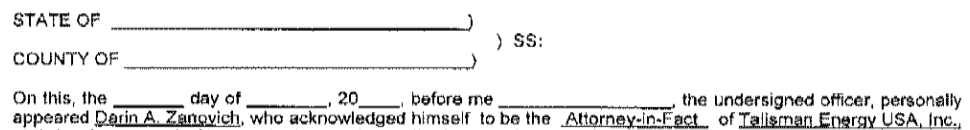

On this, the
appeared Derin A. Z dangy of therein contained by slgning the rarne of the limited liability company by himself as Attorney-in-fact.

IN WITNESS WHEREOF, I hereunto set my hand and ofticial sẹpl

My Commission Expires:

Signature/Notary Public:

CORPORATE ACKNOWLEDGMENT

STATE OF TEXA

COUNTY OF HARPIS $; s S$ :

appeared_________._. whe acknowledged hlmself to be the the undersigned officer, personally

belng authorized to do so, executed foregoing instrument for the purpose therein conteined by signing the name of the corporation by himself

IN WITNESS WHEREOF. 1 hereunto set my hand and official sepil.

My Commission Expires:

Name/Notary Fublic (print)

$\cdot 4$. 
CORPORATE ACKNOWLEDGMENT STATE OF TEXAS
COUNTY OF HARRIS \}SS:
On this, the __ day of __ who acknowledged himself to be the , the undersigned officer, personally
appeared
being authorized to do so, executed foregoing instrument for the purpose therein contained by signing the name of
the corporation by himseif

IN WITNESS WHEREOF, I hereurto set my hand and official seal.

My Cammission Expires;

Signature/Notary Public:

Name Notary Public (print);

$-5$. 


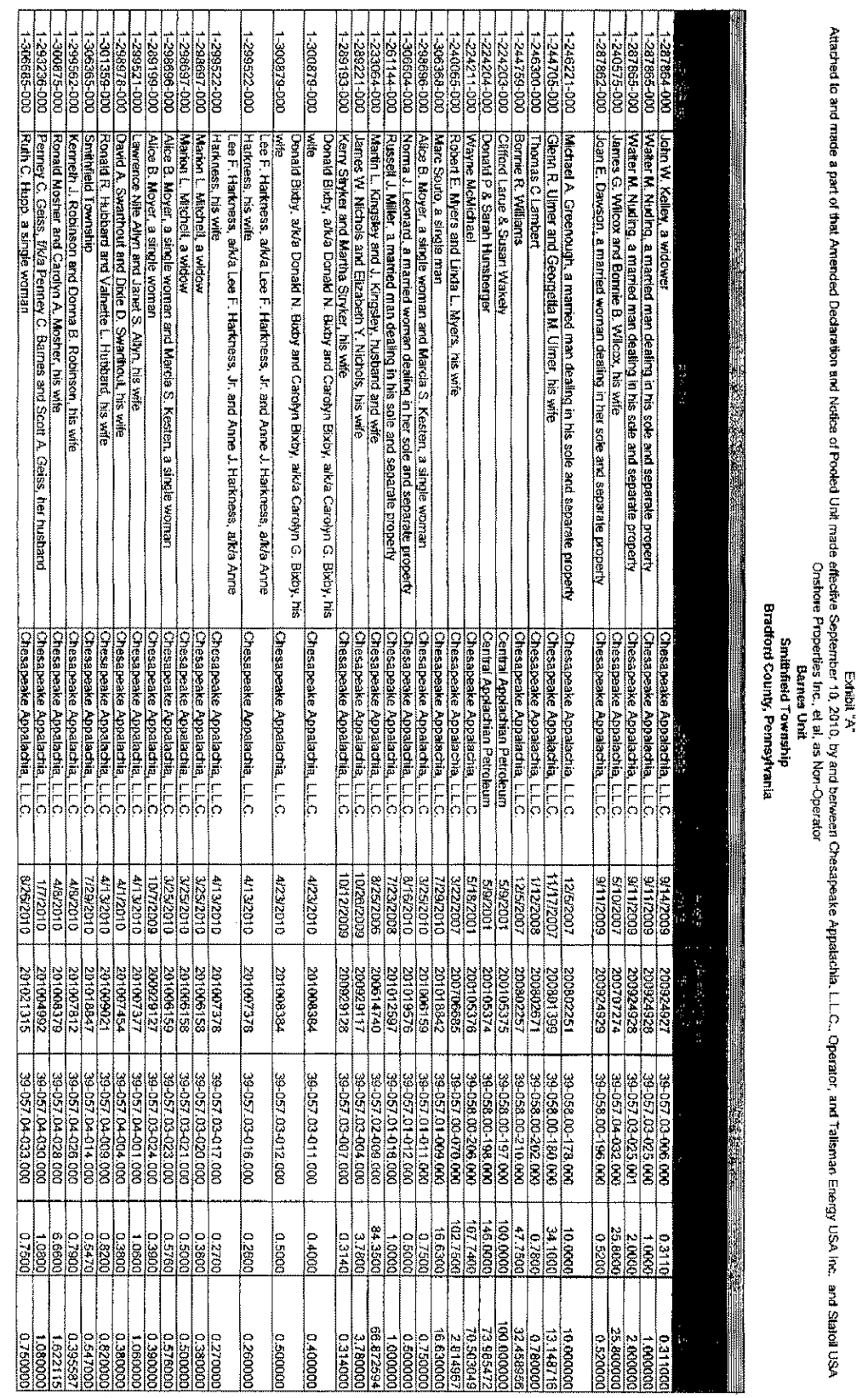

11/19/2012 3:18:27 PM

BRADFORD COUNTY, PA

Inst.\# 201113059 - Page 7 of 10 


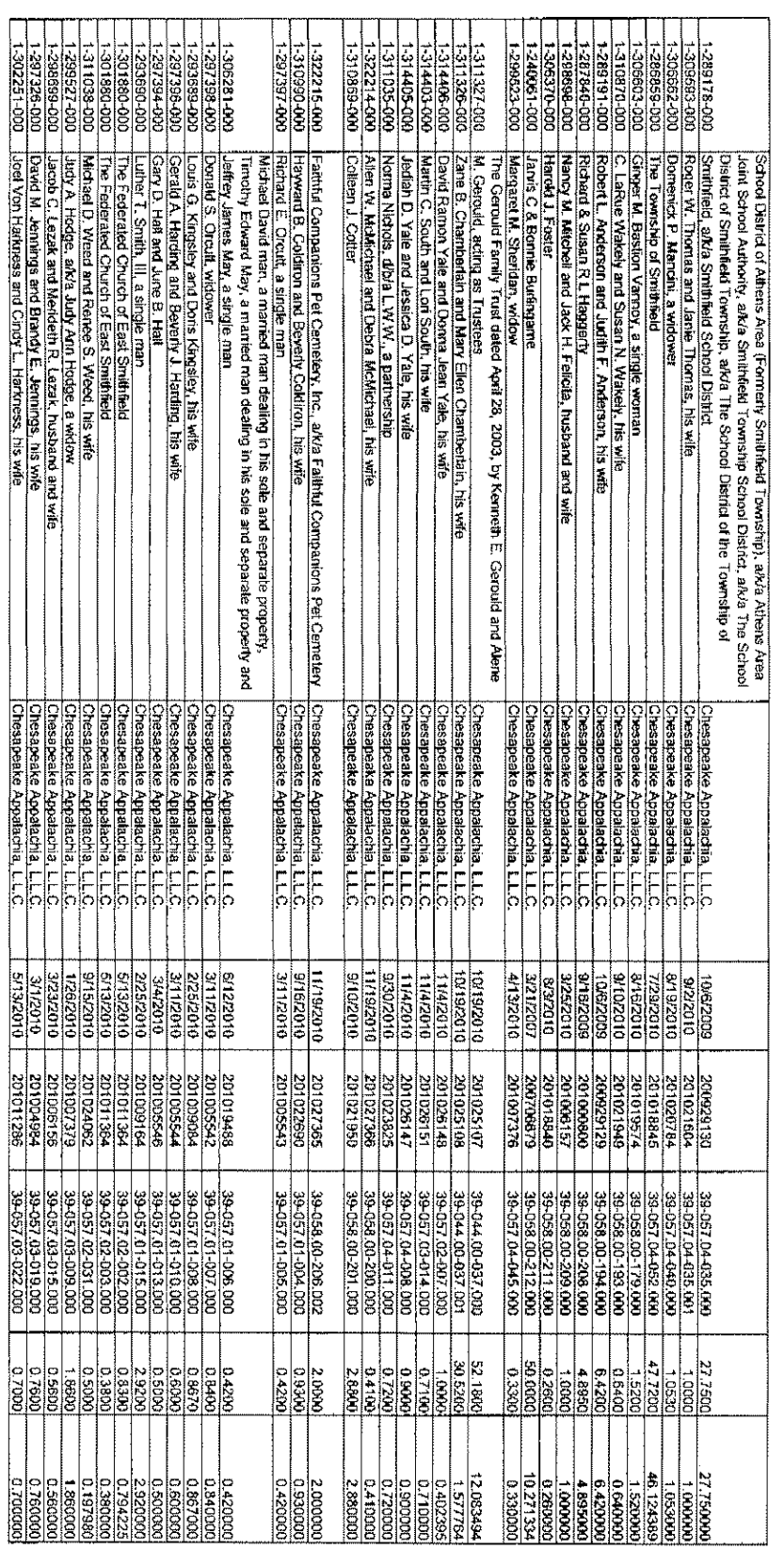

11/19/2012 3:18:27 PM

BRADFORD COUNTY, PA

Inst.\#201113059 - Page 8 of 10 


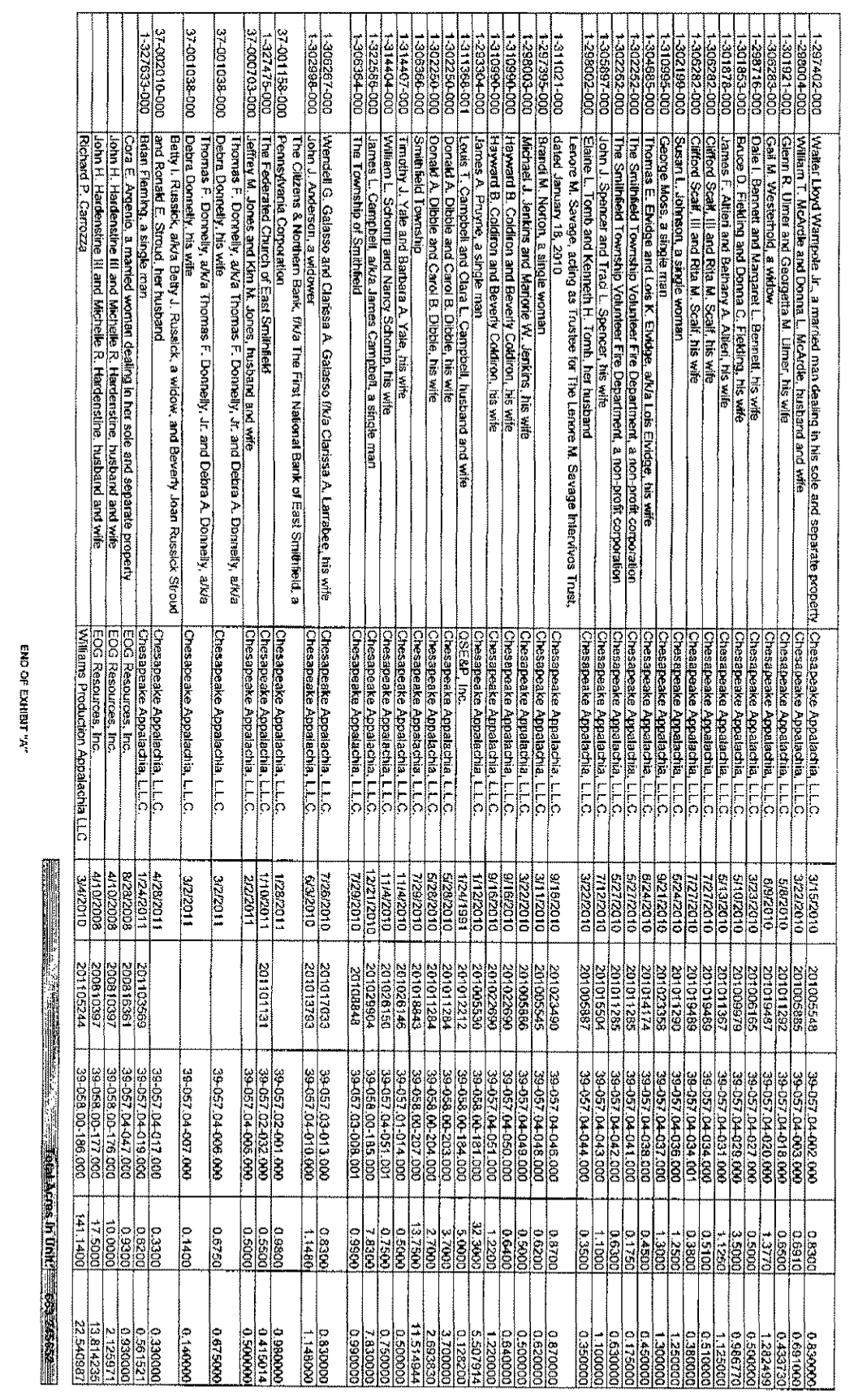

11/19/2012 3:18:27 PM

BRADFORD COUNTY, PA

Inst.\#201113059 - Page 9 of 10 
Exhibit "B"

Afteched to and made a part of that Declaration and Notice of Pooled Unit made effective September 10, 2010, by and between Chesapeake Appalachia, L.L.C., Talisman Energy USA Inc., and Statoil USA Onshore Properties Inc.

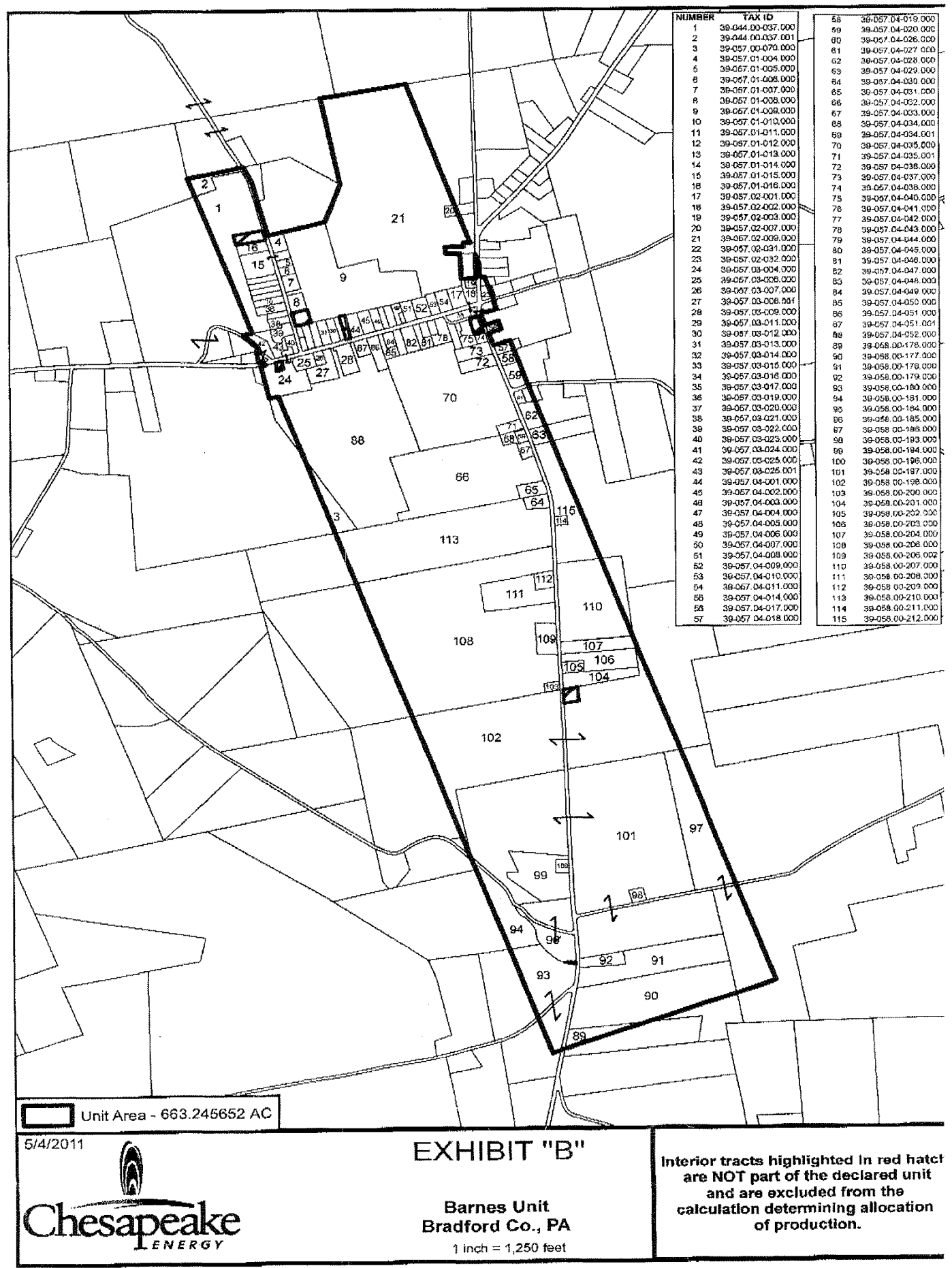

